OPEN ACCESS

Edited by:

Nikolaos E. Labrou,

Agricultural University of Athens,

Greece

Reviewed by:

Akira Inoue,

Hokkaido University, Japan

Yuan Lu,

Tsinghua University, China

${ }^{*}$ Correspondence:

Manuel Benedett

manuel.benedetti@univaq.it

Specialty section:

This article was submitted to Industrial Biotechnology,

a section of the journal

Frontiers in Bioengineering and

Biotechnology

Received: 25 January 2020 Accepted: 31 March 2020

Published: 29 April 2020

Citation:

Giovannoni M, Gramegna G, Benedetti M and Mattei B (2020) Industrial Use of Cell Wall Degrading

Enzymes: The Fine Line Between

Production Strategy and Economic

Feasibility.

Front. Bioeng. Biotechnol. 8:356

doi: 10.3389/fbioe.2020.00356

\section{Industrial Use of Cell Wall Degrading Enzymes: The Fine Line Between Production Strategy and Economic Feasibility}

\author{
Moira Giovannoni, Giovanna Gramegna, Manuel Benedetti* and Benedetta Mattei \\ Department of Life, Health and Environmental Sciences, University of L'Aquila, L'Aquila, Italy
}

Cell Wall Degrading Enzymes (CWDEs) are a heterogeneous group of enzymes including glycosyl-hydrolases, oxidoreductases, lyases, and esterases. Microbes with degrading activities toward plant cell wall polysaccharides are the most relevant source of CWDEs for industrial applications. These organisms secrete a wide array of CWDEs in amounts strictly necessary for their own sustenance, nonetheless the production of CWDEs from wild type microbes can be increased at large-scale by using optimized fermentation strategies. In the last decades, advances in genetic engineering allowed the expression of recombinant CWDEs also in lab-domesticated organisms such as E. coli, yeasts and plants, dramatically increasing the available options for the large-scale production of CWDEs. The optimization of a CWDE-producing biofactory is a hard challenge that biotechnologists tackle by testing different expression strategies and expression-hosts. Although both the yield and production costs are critical factors to produce biomolecules at industrial scale, these parameters are often disregarded in basic research. This review presents the main characteristics and industrial applications of CWDEs directed toward the cell wall of plants, bacteria, fungi and microalgae. Different biofactories for CWDE expression are compared in order to highlight strengths and weaknesses of each production system and how these aspects impact the final enzyme cost and, consequently, the economic feasibility of using CWDEs for industrial applications.

Keywords: cell wall degrading enzymes, biofactory, enzyme productivity, production cost, plant cell wall, microalgae, peptidoglycan, chitin

\section{INTRODUCTION}

The cell wall is a complex, selectively permeable layer surrounding the cell. It is found in archaea, bacteria, fungi, plants and algae. The most relevant functions of cell wall are to confer protection, structure and support to the cell; therefore, cell wall evolved to be highly resistant to a wide range of biotic and abiotic stresses. The cell wall composition varies greatly in organisms from different Kingdoms with further sub-differentiation amongst organisms of the same Kingdom. For example, plant cell walls are mainly composed of polysaccharides arranged in complex structures while the structural proteins are minor components; on the other hand, bacterial peptidoglycan is composed of polysaccharidic chains crosslinked by many peptide bridges. Heterogeneity and complexity of the cell wall are crucial, since it is the first line of defense against pathogens and predator attacks. 
In this regard, "attacking" organisms evolved different enzymes specialized in cell wall degradation, named as Cell Wall Degrading Enzymes (CWDEs). Intriguingly, the same CWDE can work both as attack and defense weapon, depending on the nature of the producing organism. For example, lysozyme produced by lytic bacteriophages hydrolyses peptidoglycan to favor the release of the viral progeny from the bacterial cell (Lavigne et al., 2004) while animals produce lysozyme to protect themselves against pathogenic bacterial infection (Ragland and Criss, 2017). Moreover, organisms evolved endogenous CWDEs to remodel their own cell wall structures during development. In general, endogenous CWDEs are characterized by milder degrading activities compared to those of exogenous nature and are therefore of lower industrial relevance. CWDEs are a highly heterogenous family including glycosyl-hydrolases (the most abundant class of enzymes), oxido reductases, lyases and esterases. The different CWDEs are classified in the Carbohydrate Active Enzymes (CAZy) database ${ }^{1}$, based on the sequence homology of their catalytic domains. Degradation of cell wall polysaccharides not only allows pathogens to penetrate inside the host cell, but also to release sugars for their own growth, thus sustaining the infection process. In the last decades, the use of cell wall polysaccharides or their derivatives for biofuel and chitosan production as well as the necessity to eliminate cell wall residues from products such as food, beverage, paper and textiles strongly boosted the use of CWDEs in many industrial applications (Benedetti et al., 2019a). Here, different CWDEs of industrial interest will be reviewed, indicating the most promising CWDE-expressing biofactories and the current methods employed for the large-scale production of CWDEs. Moreover, different CWDE-expressing biofactories, including wild type and transgenic organisms, will be analyzed in term of CWDE yield, enzyme productivity and production costs in order to highlight strengths and weaknesses of each expression system in the perspective of a possible large-scale application.

\section{ENZYMATIC CHARACTERISTICS AND INDUSTRIAL APPLICATIONS OF CWDES}

In this section, the most studied CWDEs have been classified based on their target cell wall and substrate specificity. The main industrial applications for each CWDE category are summarized. In the last paragraph, the industrial potential of CWDEs from hyperthermophilic microorganisms is discussed.

\section{CWDEs Toward the Plant Cell Wall}

The plant cell wall is composed mostly of carbohydrate-based polymers, i.e., cellulose, hemicelluloses and pectins. All the plant cells that are in developmental expansion have a primary cell wall that is constantly remodeled, composed of cellulose fibers embedded in a hemicellulose-pectin matrix (Burton et al., 2010). At the end of the plant cell development, i.e., once the cell has ceased to expand, a secondary layer composed by cellulose, hemicellulose and lignin is deposited close to the

${ }^{1}$ www.cazy.org primary cell wall; the architecture of such assembly varies among different cell types, being optimized to perform cell-specific functions (Keegstra, 2010; Höfte and Voxeur, 2017; Zhong et al., 2019). Lignocellulose from agricultural feedstocks is formed by clusters of secondary cell walls; in terms of energetic potential, lignocellulose appears as a deposit of reducing power stored in its complex structure and composition. Phytopathogens as well as saprophytes secrete a wide array of CWDEs to open a breach in the plant cell wall; the degradation of this complex matrix into simple sugars significantly contribute to the global carbon cycle (Gibson et al., 2011; Choi et al., 2013; Glass et al., 2013). CWDEs are divided in many categories and sub-categories depending on their substrate specificities toward the diverse cell wall polysaccharides. The most important CWDEs directed toward the plant cell wall polysaccharides are:

\section{CWDEs With Cellulolytic Activity}

Cellulose is a $\beta$-1,4-homopolymer formed by repeated units of cellobiose, i.e., a disaccharide of D-glucose. Cellulose chains interact with each other to form fibrils and, at macroscale, fibers. Cellulolytic enzymes include glycosyl-hydrolases (i.e., cellulases) and oxidoreductases (i.e., lytic polysaccharide monooxygenases, LPMOs) (Singhania et al., 2013; Sandhu et al., 2018; Binod et al., 2019). Cellulases and LPMOs act in a synergistic way to degrade the amorphous and crystalline regions of cellulose, respectively (Dimarogona et al., 2012; Martínez et al., 2017; Obeng et al., 2017; Figure 1A). Cellulases degrade the amorphous region of cellulose by three main enzymatic activities: endo-glucanase, exo-glucanase (i.e., cellodextrinase and cellobiohydrolase) and $\beta$-glucosidase activities. Many cellulases (mainly endo- and cellobiohydrolases) are expressed as modular enzymes in which the catalytic domain $(\mathrm{GH})$ is linked to a carbohydrate binding module (CBM). The presence of CBM is not essential for cellulase activity although it could increase both the recognition and binding of the substrate (Bayer et al., 1998; Payne et al., 2015; Sajith et al., 2016; Ahmed and Bibi, 2018).

Cellulolytic oxidases (LPMOs) are characterized by a broader substrate specificity with respect to cellulases, since they can also attack the crystalline region of cellulose. LPMOs catalyse the oxidative cleavage of crystalline cellulose thus exhibiting a synergistic action with hydrolytic enzymes (endoglucanases and cellobiohydrolases) (Villares et al., 2017; Hu et al., 2018). LPMO cleaves glycosidic linkages, leading to the formation of oxidized glucose units at $\mathrm{C} 1$ position (gluconic acid) and/or at the C4 position (4-ketoglucose) (Eibinger et al., 2014; Vaaje-Kolstad et al., 2017; Valenzuela et al., 2019). The copper-containing active site of LPMO must be reduced after each reaction in order to guarantee the enzyme turnover and different reducing mechanisms that can assist LPMO recycling have been identified. Electrons can be restored to LPMO through the following mechanisms: (i) cellobiose oxidation by cellobiose dehydrogenase (Loose et al., 2016; Laurent et al., 2019), (ii) monolignol oxidation upon lignin degradation (Brenelli et al., 2018) and (iii) $\mathrm{H}_{2} \mathrm{O}_{2}$ mediated reduction (Müller et al., 2018; Eijsink et al., 2019). The latter mechanism was elucidated for the first time in 2017, paving the way to novel strategies for improving cellulose degradation. 


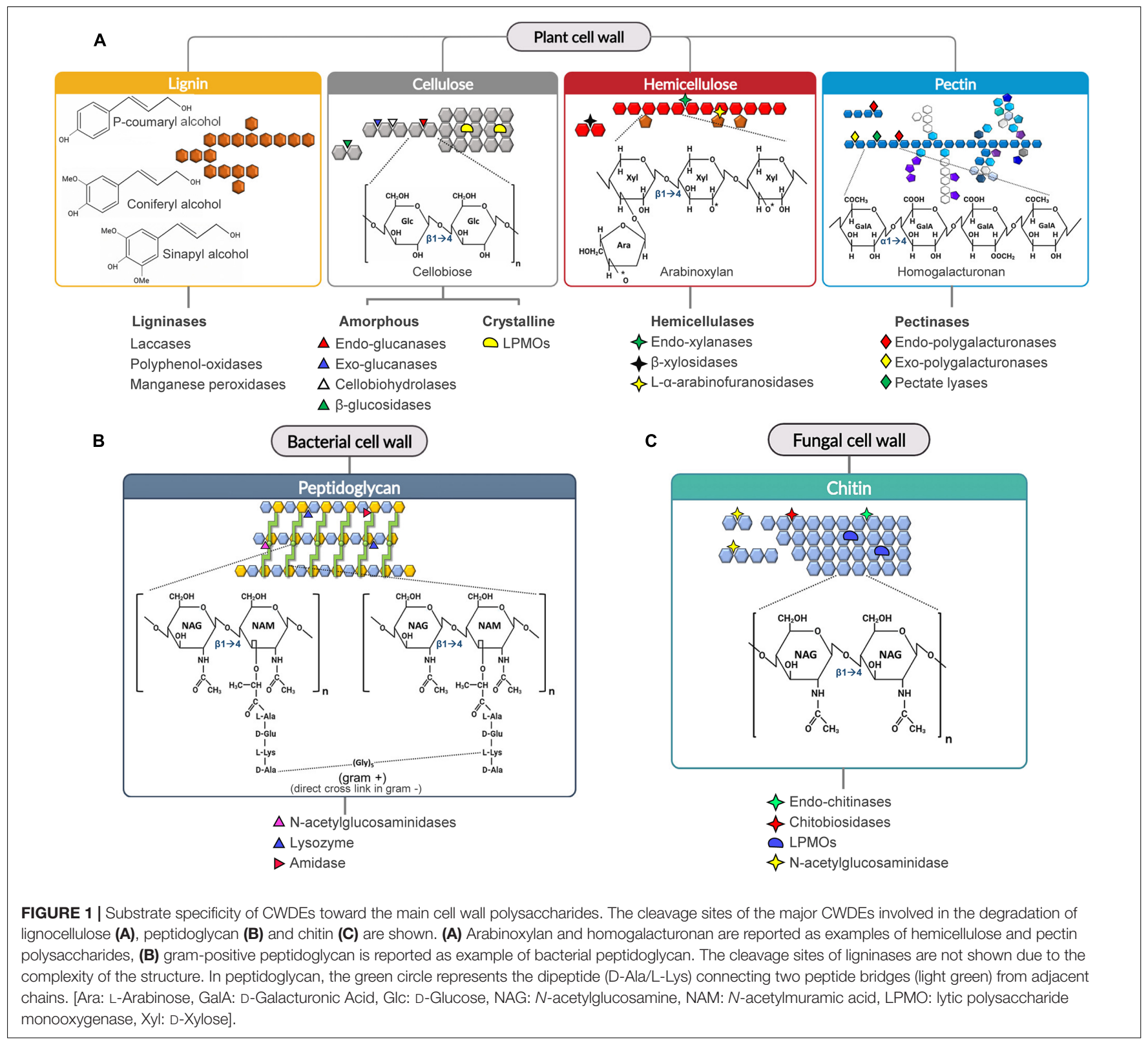

\section{CWDEs With Hemicellulolytic Activity}

Hemicellulose is a branched and highly heterogenous polysaccharide composed of pentoses (e.g., xylose and arabinose), hexoses (e.g., mannose, glucose and galactose) and acidic sugars (e.g., galacturonic and glucuronic acid) (Scheller and Ulvskov, 2010; Zhao et al., 2012). Due to its high complexity, many hemicellulolytic enzymes are required for the efficient degradation of hemicellulose. Efficient degradation of xylan, i.e., the most abundant hemicellulose in agricultural wastes, is particularly relevant to prevent the formation of by-products with inhibitory activity toward cellobiohydrolases (Baumann et al., 2011; Momeni et al., 2015; Malgas et al., 2019) and downstream processes such as yeast fermentation to produce bioethanol (Jönsson and Martín, 2016). Unlike cellulose, hemicellulose is mainly hydrolysed by glycosyl-hydrolases. The most used in industrial applications are endo-acting CWDEs such as xylanases, mannanases and galactanase, and exo-acting CWDEs such as $\beta$-galactosidases, $\beta$-xylosidase, $\beta$-mannosidase and L- $\alpha$-arabinofuranosidase (Figure 1A).

\section{CWDEs With Pectinolytic Activity}

Pectin is a branched acidic $\alpha$ - $(1,4)$-polysaccharide consisting mainly of D-galacturonic acid and of various proportions of other sugars including L-rhamnose, L-arabinose, D-galactose and D-xylose. Pectin is composed of different domains, i.e., homogalacturonan, xylogalacturonanan, rhamnogalacturonan I and rhamnogalacturonan II, covalently linked to each other (Ridley et al., 2001; Caffall and Mohnen, 2009). In homogalacturonan the D-galacturonic acid units can be methylesterified (at C6) and/or O-acetylated (at C2 and/or C3 hydroxyl 
groups). Pectin is degraded by microbial glycosyl-hydrolases (i.e., endo-polygalacturonases and exo-polygalacturonases) and lyases (i.e., pectate lyases) (Figure 1A).

\section{CWDEs With Ligninase Activity}

Lignin is a complex phenolic polymer derived from phenylpropanoid monolignols, that confers strength and rigidity to the plant cell wall (Figure 1A); hence, its degradation can greatly improve the digestibility of lignocellulosic biomass. Lignin occludes the cellulose-hemicellulose assembly thereby increasing its recalcitrance to enzymatic hydrolysis, due to its hydrophobic nature and to the intrinsic characteristic of lignin to irreversibly adsorb to the CBM of CWDEs, thus poisoning the enzymes (Gao et al., 2014; Li et al., 2016). Lignin degradation is mainly catalyzed by ligninases, a general term that includes laccases, polyphenol-oxidases and (manganese)-peroxidases (Figure 1A).

\section{Industrial Applications of CWDEs Toward the Plant Cell Wall}

Sugars from lignocellulosic wastes can be exploited as carbon source for the production of second generation biofuels (e.g., bioethanol by yeast fermentation) and biogas (methane by anaerobic digestion of methanogens) (Benedetti et al., 2019a; Herrero Garcia et al., 2019); however, the low efficiency of lignocellulose degradation by CWDEs, together with the high cost of commercial CWDE-based blends, make the entire process not competitive over chemical and physico-chemical treatments (Saini et al., 2015). Although chemical treatments are polluting, their use allows to reach higher degradation efficiencies at reduced cost compared to biological methods. In this perspective, the optimization of CWDE-expressing biofactories is mandatory to increase the sustainability of biological treatment of biomasses. Enzymatic degradation of lignocellulose may be increased by exploiting the synergistic action between different CWDEs. Many efforts have been spent by companies aiming at identifying the best-performing CWDE-combinations with maximum hydrolysis yield and minimum enzyme loading; as a consequence, many commercial enzyme-based products [e.g., Cellic ${ }^{\circledR}$ CTech (Novozymes A/S, Bagsværd, Denmark), MiaMethan ${ }^{\circledR}$ ProCut (MIAVIT GmbH, Essen, Germany)] are protected by strict commercial laws so that their composition and production process are confidential. In addition to the biofuel sector, endo-glucanases, exo-glucanases and $\beta$-glucosidases are widely used also in food and feed processing, bakery, textile, cellulose pulping and paper industry as well as in the production of dietary supplements and nutraceuticals (Jayasekara and Ratnayake, 2019; Figure 2). Notably, $\beta$-glucosidases can be also used for removing lactose from dairy products due to their broad substrate specificity (Singh et al., 2016). Endo-xylanase and xylosidases are used in feed and bakery industry, while $\beta$-galactosidase and $\alpha$-L-Arabinofuranosidase are employed in food processing (Figure 2). Pectinolytic enzymes are widely used in several industrial applications such as food and beverage processing, olive oil extraction, recycling of wastepaper, textile industry and wine/tea processing (Garg et al., 2016) (Figure 2). Ligninases have a great potential for industrial applications, although mechanisms underlying lignin degradation are largely still unknown. Currently, the use of ligninases is mainly restricted to the paper industry for the bleaching of cellulose pulp (Figure 2).

\section{CWDEs Toward the Bacterial Cell Wall}

The bacterial cell wall is mainly composed of peptidoglycan, a heteropolymer consisting of amino sugars and oligopeptides. The backbone chain is formed by alternating residues of $\beta$-1,4(linked) $\mathrm{N}$-acetylglucosamine (NAG) and $\mathrm{N}$-acetylmuramic acid (NAM) (Vollmer et al., 2008; Dörr et al., 2019); NAM residues from adjacent chains, in turn, are interconnected by peptide bridges of variable length, ranging from three to five amino acids. Although the peptidoglycan composition is conserved among bacterial species, the overall cell wall architecture varies between Gram-positive, Gram-negative and acid-fast bacteria (Desvaux et al., 2018). The degradation of peptidoglycan is performed by amidases and glycosidases (Figure 1B; Alcorlo et al., 2017; Vermassen et al., 2019).

\section{CWDEs With Amidase Activity}

Amidase (N-acetylmuramoyl-L-alanine amidases, NALAAs) cleaves the peptide bridge of peptidoglycan by hydrolysing the amide bond connecting the first amino acid (L-alanine) to the NAM residue (Höltje, 1995; Vollmer et al., 2008; Irazoki et al., 2019). Amidases are grouped based on their catalytic site and substrate specificity (i.e., short, mid-chain amides, arylamides, $\alpha$-aminoamides and $\alpha$-hydroxyamides). These enzymes are associated in compact multimeric structures and are resistant both to high temperature and alkaline conditions (Sharma et al., 2009).

\section{CWDEs With Glycosidase Activity}

Glycosidases with degrading activity toward peptidoglycan comprise $\mathrm{N}$-acetyl-glucosaminidase (NAGases) and lysozyme. NAGase hydrolyses the glycosidic bond between the N-acetyl$\beta$-D-glucosamine residue and the closer monosaccharide; this type of bond is present in various oligosaccharides, chitin and $\mathrm{N}$-glycans (Karamanos, 1997). Lysozyme hydrolyses the $\beta-1,4$ linkage between NAM and NAG residues in the peptidoglycan backbone (Herlihey and Clarke, 2017).

\section{Industrial Applications of CWDEs Toward the Bacterial Cell Wall}

The industrial applications of amidases ranges from biomedical field (clinical diagnostics and health monitoring) to the food industry as flavor enhancers (Nandakumar et al., 2003; Ghonemy, 2014; Kumar et al., 2014; Sathish et al., 2018). NAGases are mainly employed in organic chemistry to produce synthetic oligosaccharides (Scigelova and Crout, 1999). Lysozyme has many industrial applications ranging from food processing to medicine. It is used as antibacterial agent and pharmacological adjuvant for its capability to hydrolyse bacterial peptidoglycan and is also used as preservative in food processing with the identification code E1105. Moreover, lysozyme is used in combination with chitinases and cellulases to degrade chitin into chitosan, i.e., a polysaccharide formed by the repeated unit $\beta$ 1,4-D-glucosaminyl-N-acetyl-D-glucosamine (Pillai et al., 2009). 


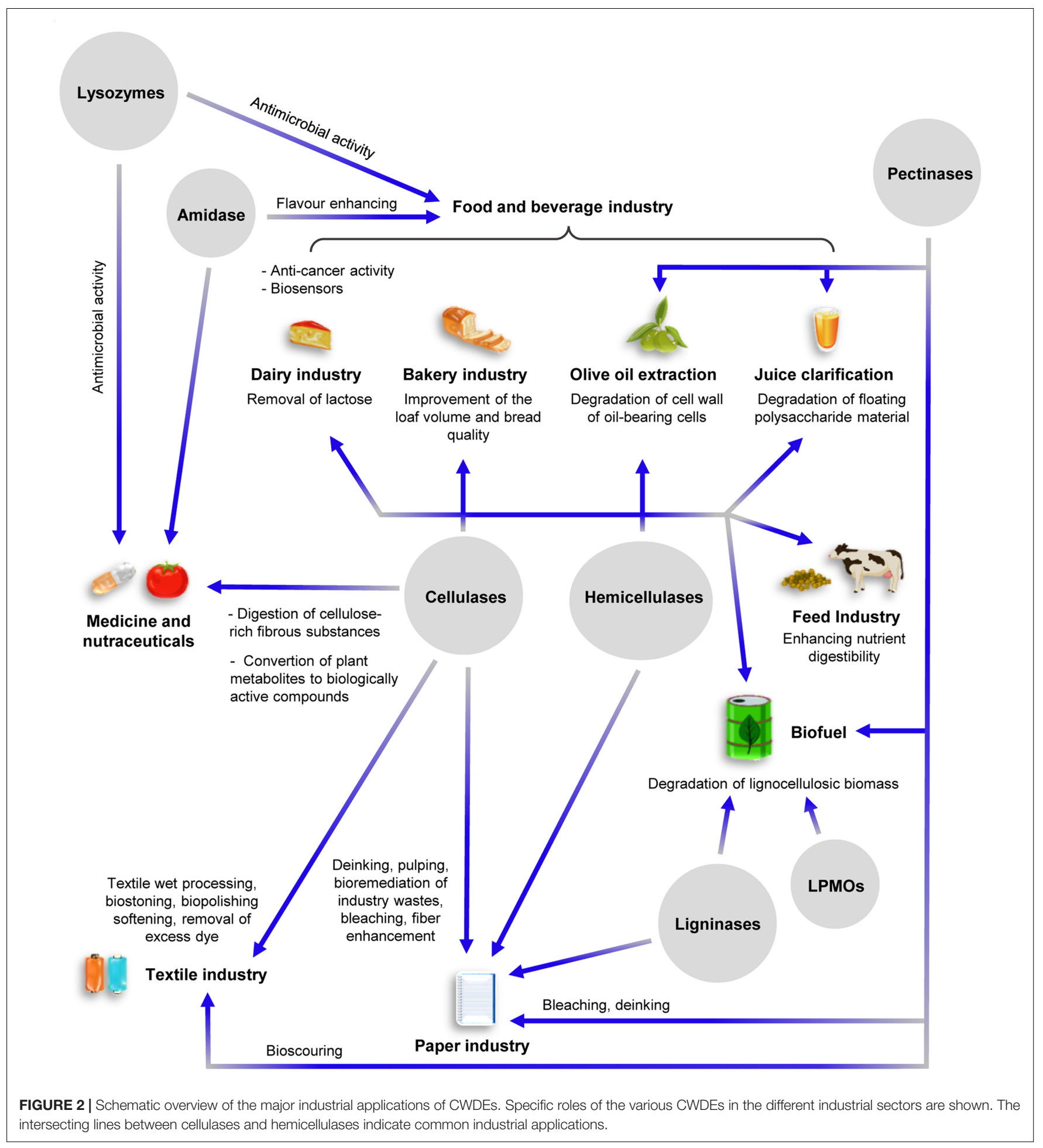

Chitosan and its derivatives are employed in the production of materials for medical surgery, for tissue engineering and drug delivery (Rinaudo, 2006; Zhang et al., 2010). Recently, chitosan was also used as component of nutraceuticals due to its ability to stimulate the immune system (Fong and Hoemann, 2018; Abdel-Tawwab et al., 2019; Figure 2).

\section{CWDEs Toward the Fungal Cell Wall}

Fungal cell wall is a two-layered structure, with a hydrophobic and rigid inner layer, consisting of a branched $\beta$-1,3(linked) gluco-polysaccharide cross-linked to small portions of chitin (Kang et al., 2018); this layer is covalently linked to galactomannan and other branched glucans that, together, 
form the outer layer of the fungal cell wall (Gow et al., 2017; Kang et al., 2018). The outer layer is more hydrophilic and flexible than the inner layer due to the lack of chitin. Chitin is a homopolymer composed of $\beta-1,4$ (linked) NAG residues. Notably, chitin is also a major component of the exoskeletons of arthropods, crustaceous shells, mollusc radula and cell walls of several microalgae species (Cauchie, 2002). Chitin naturally occurs in three different crystalline structures depending on the orientation of the constituting microfibrils. $\alpha$-type and $\beta$-type chitin are characterized by antiparallel and parallel chains, respectively; $\gamma$-type chitin is a mixture of $\alpha$-type and $\beta$-type chitin (Rudall and Kenchington, 1973). Chitin degradation is performed by chitinases, i.e., glycosyl-hydrolases that cleave the glycosidic bond between the NAG residues of chitin (Figure 1C).

\section{CWDEs With Chitinolytic Activity}

Chitinases are divided in endo-chitinases and exo-chitinases depending on their mode of action. Endo-chitinases hydrolyze both $\alpha$ - and $\beta$-type chitin releasing chito-oligosaccharides with different degree of polymerization, including small-size oligosaccharides such as di-acetylchitobiose, chitotriose, and chitotetraose. Exo-chitinases comprise chitobiosidases and $\beta$ $1,4-\mathrm{N}$-acetylglucosaminidases. Chitobiosidase acts on the nonreducing end of the chitin chain by releasing di-acetylchitobiose (Harman, 1993), while $\beta-1,4-\mathrm{N}$-acetylglucosaminidase cleaves chito-oligomers and chitobiose into NAG monomers.

\section{Other CWDEs With Degrading Activity Toward Chitin}

Other CWDEs are involved in chitin degradation by synergistically acting with chitinases, namely cellulases and LPMOs (see section "CWDEs Toward the Plant Cell Wall” for further details). Some LPMOs orthologs are more active in degrading crystalline chitin rather than cellulose (Vaaje-Kolstad et al., 2010; Bissaro et al., 2018).

\section{Industrial Applications of CWDEs Toward the Fungal Cell Wall}

Degradation of chitin by chitinases releases oligomers with different degree of polymerization that have applications in the biomedical and nutraceutical fields. In addition to chitin hydrolysis, chitinases are attracting great interest because of their potential application in agriculture, cosmetics and wastewater treatment (Synowiecki and Al-Khateeb, 2003; Park et al., 2011; Stoykov et al., 2015; Figure 2). Although chitin is the second most abundant biopolymer after cellulose, the use of chitinases in industrial processes is limited mainly by the lack of efficient chitinase-expressing biofactories (Stoykov et al., 2015).

\section{CWDEs Toward the Microalgal Cell Wall}

Microalgae are found in a wide range of habitats and have adapted to a variety of environmental conditions by evolving a great genetic diversity, making them a precious source of interesting and useful metabolites (Benedetti et al., 2018a). However, the extraction of metabolites from microalgae represents one of the major bottlenecks limiting their potential in industrial applications. Enzymatic treatment is much less efficient than physical rupture, pointing to the necessity of developing CWDE blends effective in the degradation of the microalgal cell wall. It is worth noting that a univocal structural model of the microalgal cell wall cannot be established likely due to the broad adaptive diversification of microalgae. For example, the cell wall of the unicellular green alga Chlamydomonas reinhardtii is formed by seven layers of hydroxyproline-rich glycoproteins (Imam et al., 1985) while the cell wall of the marine microalga Nannochloropsis gaditana is composed by polysaccharides, i.e., cellulose and algaenan (Scholz et al., 2014). In this paragraph, we will focus on the cell wall of Chlorella vulgaris, one of the most employed oleaginous microalgae with applications ranging from the biofuel sector (i.e., production of biodiesel through lipid transesterification) to nutraceutical (Benedetti et al., 2018a; Dall'Osto et al., 2019). Although C. vulgaris is a well-studied organism compared to other microalgae species, the degradation of its cell wall is still a high hurdle. Preliminary studies demonstrated that the cell wall of $C$. vulgaris and other related microalgae species had rigid wall components embedded within a more plastic polymeric matrix. The acidhydrolysis of this polymeric matrix revealed the presence of acid sugars, rhamnose, arabinose, fucose, xylose, mannose, galactose and glucose (Takeda, 1991). Subsequently, Gerken and collaborators showed the cell wall of $C$. vulgaris is constituted by a heterogeneous bilayer matrix; the inner layer is mainly composed of polysaccharides such as cellulose and pectin, while the external one is composed by a robust chitin-like glucan (Gerken et al., 2013).

\section{CWDEs With Degrading Activity Toward C. vulgaris}

Lysozyme from hen egg-white is the most effective CWDEs in degrading the cell wall of this microalga, followed by the endo-chitinase from Streptomyces griseus, the sulfatases from Helix pomatia, $\beta$-glucuronidase and laminarinase (Gerken et al., 2013; Kumar et al., 2018). Sulfatases belong to the esterase class catalyzing the hydrolysis of sulfate esters in steroids, carbohydrates and proteins (Parenti et al., 1997). The sulfatases from $H$. pomatia are divided in $\mathrm{H} 1$ - and $\mathrm{H} 2$-type sulfatase, depending on their substrate specificity. $\beta$-glucuronidase is a glycosyl-hydrolase catalyzing the hydrolysis of $\beta$-D-glucuronic acid residues from the non-reducing end of mucopolysaccharides (Sinnot, 1998), while laminarinase catalyzes the endo-hydrolysis of 1,3- or 1,4-linkages in $\beta$-D-glucans when the glucose residue involved in the linkage is substituted at C3 position (Salyers et al., 1977). At present, the enzymatic degradation of C. vulgaris requires huge amounts of CWDEs making the process not competitive at industrial scale (Gerken et al., 2013; Kumar et al., 2018). In conclusion, the many different (and apparently unrelated) enzymatic activities used to degrade C. vulgaris reflect on one hand the hybrid nature of its cell wall, and on the other hand point to the necessity of further investigations.

\section{CWDEs From Hyperthermophiles}

Cell wall degrading enzymes from hyperthermophilic microbes (HCWDEs) represent a category of high industrial interest due to their peculiar enzymatic characteristics. These enzymes are also known as "Hot Extremozymes" since they are active at temperatures ranging from 70 to $100^{\circ} \mathrm{C}$ (Sarmiento et al., 
2015). The high temperature required for optimal activity and stability of HCWDEs allows faster and more effective reactions (Yeoman et al., 2010). Moreover, elevated temperature prevents undesired growth of contaminating microbes during the catalysis, thus improving the conversion yield of cell wall polysaccharides into simple sugars. Proteinaceous CWDEinhibitors, that are widely distributed in the plant cell wall as a defense mechanism (York et al., 2004; Juge, 2006; Mohammadzadeh et al., 2012; Kalunke et al., 2015), are inactivated by high temperature, thus avoiding interference with the enzymatic reaction. Another important feature of HCWDEs is protein stability that allows prolonged storage at room temperature and resistance to harsh conditions, e.g., the presence of aggressive chemicals, anionic/non-ionic detergents and extreme pH (Benedetti et al., 2019b), that can be exploited to deconstruct more efficiently cell wall recalcitrant material. Stability of HCWDEs also allows an efficient enzyme recycling over time, thus reducing the total enzyme loading in industrial practices. However, maintaining industrial processes at high temperature for a long time requires a great expense of energy, therefore a further step toward sustainability may imply the use of HCWDEs in industrial plants with excess heat that can be recycled in order to limit the additional heating cost. Up to now, not all the CWD-activities toward plant cell wall polysaccharides are available in their respective hyper-thermostable version. In particular, while hyper-thermostable orthologs have been isolated for mesophilic cellulases, hemicellulases and ligninases, the exo-polygalacturonases from Thermotoga maritima and Caldicellulosiruptor bescii (Kluskens et al., 2005; Chen et al., 2014) are the only pectinases isolated so far, and neither endo-polygalacturonases nor pectate lyases of hyperthermophilic nature have been identified yet. Similarly, LPMOs from the thermophilic bacterium Thermobifida fusca are the only available option for the degradation of crystalline cellulose at mid-high temperature (Moser et al., 2008). Other carbohydrate active enzymes with important industrial applications are amylases, employed in starch conversion, biofuel production, brewing, bakery, textile, detergent and paper industry. Well-known $\alpha$ amylase producers are bacteria belonging to the genus Bacillus such as B. subtilis, B. licheniformis, and B. amyloliquefaciens (Jujjavarapu and Dhagat, 2019), while $\beta$-amylases are mainly obtained by plants such as barley (Hordeum vulgare) and sweet potato (Ipomoea batatas) (Saini et al., 2017). Unlike $\alpha$ amylases from Bacillus species, $\beta$-amylases are less resistant to high temperature; in this regard, the use of a hyperthermostable $\beta$-amylase may be a cost-effective choice for reducing the amount of enzyme used during the catalysis; to date, the only $\beta$-amylase of hyperthermophilic nature with proven activity was identified from Clostridium thermosulfurogenes (Nipkow et al., 1989).

Other HCWDEs of industrial interest are those degrading fungal and bacterial cell wall polysaccharides. A highly thermostable chitinase was isolated from Pyrococcus furiosus (Oku and Ishikawa, 2006); this enzyme showed marked degrading activity toward both the amorphous and $\beta$-type chitin, while it was less active toward $\alpha$-type chitin. Noteworthy, highly thermostable lysozymes were also identified; they were isolated from hyperthermophilic bacteriophages such as the Pseudomonas phage $\varphi$ KMV (Lavigne et al., 2004); the substrate specificity of thermostable lysozymes is not comparable to that of egg-white lysozyme commonly used in food processing, thereby precluding their exploitation in this field.

The industrial use of HCWDEs has been so far limited by the fact that they cannot be efficiently produced at large-scale by wild-type microbes. Production of recombinant HCWDEs may be carried out in E. coli by high cell-density fermentation. As an alternative expression system, the last advances in plant biotechnology allowed the large-scale production of recombinant HCWDEs also in tobacco plants (Castiglia et al., 2016; Schmidt et al., 2019) (see section "Yield and Cost Analysis of Plant CWDE-Producing Biofactory"). In Table 1, a selection of CWDEs with both consolidated and potential use in industrial applications is proposed. According to this selection, the use of HCWDEs is suggested for biofuel production rather than food processing since the high temperature of action may alter the organoleptic properties of food and beverages. The techno-economic aspects of different CWDEexpressing biofactories are discussed in section "YIELD AND COST ANALYSIS OF ENZYMES FROM DIFFERENT CWDEPRODUCING BIOFACTORIES.”

\section{LARGE-SCALE PRODUCTION OF CWDES}

Cell wall degrading enzymes can be produced at largescale through different expression strategies. Nowadays, microbial fermentation still plays a prominent role in the production of commercial enzymes. However, although both endogenous and recombinant CWDEs may be expressed through microbial fermentation, recent advancement in genetic engineering of land-plants and microalgae increased the spectrum of potential expressing hosts. In this section, the biotechnological aspects of conventional and novel CWDE-expressing biofactories are discussed (Table 2).

\section{Microorganisms as CWDE-Producing Biofactories}

Cellulolytic and pectinolytic microbes are mainly cultivated by submerged and solid-state fermentation. In submerged fermentation, bacteria and filamentous fungi are grown in liquid medium containing nutrients, macro and micro-elements under sterile conditions and continuous oxygen supplementation. The most appropriate carbon source is selected depending on the type of expressed CWDE, e.g., glucose and galacturonic acid for optimal production of cellulases and polygalacturonases, respectively. Submerged fermentation is usually operated in fed-batch or continuous culture. In fed-batch cultures, enzyme production occurs mainly during the first phase of biomass growth. Subsequently, the growth rate in the culture is maintained by adding nutrients at different time-points, 
TABLE 1 | Industrial application of CWDEs.

\begin{tabular}{|c|c|c|c|c|c|c|c|c|c|}
\hline \multirow{2}{*}{$\begin{array}{l}\text { Uniprot } \\
\text { code }\end{array}$} & \multirow{2}{*}{ Source } & \multirow{2}{*}{$\begin{array}{l}\text { Catalytic } \\
\text { domain }\end{array}$} & \multirow{2}{*}{ Enzyme } & \multicolumn{4}{|c|}{ Enzyme features } & \multirow{2}{*}{$\begin{array}{l}\text { Cell-wall products } \\
\text { (intermediate-, } \\
\text { end-product) }\end{array}$} & \multirow{2}{*}{ References } \\
\hline & & & & $\begin{array}{l}\text { Reference } \\
\text { substrate }\end{array}$ & $\mathrm{T}_{\text {opt }}\left({ }^{\circ} \mathrm{C}\right)$ & $\mathrm{pH}_{\text {opt }}$ & $\begin{array}{l}\text { Activity } \\
\mu \mathrm{mol} / \mathrm{min}^{\star} \mathrm{mg}\end{array}$ & & \\
\hline P96492 & T. neapolitana & $\mathrm{GH} 12$ & $\begin{array}{l}\text { Endo-1,4- } \beta \text { - } \\
\text { glucanase }\end{array}$ & PASC & 106 & 6.3 & 38.5 & cellodextrins, cellobiose & Bok et al., 1998 \\
\hline 008428 & & & & & 95 & 6.0 & 9.45 & cellodextrins, cellobiose & \\
\hline P10474 & C. saccharolyticus & GH5 & Cellobiohydrolase & $p N P C$ & 80 & 5.5 & 0.62 & Cellobiose & Park et al., 2011 \\
\hline Q51723 & P. furiosus & $\mathrm{GH} 1$ & $\beta$-glucosidase & cellobiose & 104 & 5.0 & 470 & D-glucose & Kengen et al., 1993 \\
\hline Q60042 & T. neapolitana & $\mathrm{GH} 10$ & $\begin{array}{l}\text { Endo-1,4- } \beta- \\
\text { xylanase }\end{array}$ & oat xylan & 103 & 5.5 & 111.3 & xylo-oligomers, D-xylose & Zverlov et al., 1996 \\
\hline В9K9B3 & & GH53 & $\begin{array}{l}\text { endo- } \beta-1,4- \\
\text { galactanase }\end{array}$ & galactan & 90 & 6.5 & $159^{\star}$ & $\begin{array}{l}\text { galacto-oligomers, } \\
\text { D-galactose }\end{array}$ & $\begin{array}{l}\text { Benedetti et al., } \\
2019 a\end{array}$ \\
\hline В9КС33 & & GH51 & $\begin{array}{l}\alpha-L- \\
\text { arabinofuranosidase }\end{array}$ & pNPAF & 90 & 5.0 & $147^{\star}$ & L-arabinose & \\
\hline Q9RIK7 & & GH5 & $\beta$-mannosidase & mannobiose & 92 & 7.0 & 56 & D-mannose & Parker et al., 2001 \\
\hline Q9RIK9 & T. maritima & & $\beta$-mannanase & $\begin{array}{l}\text { locust bean } \\
\text { gum }\end{array}$ & 92 & 7.1 & 3.8 & $\begin{array}{l}\text { manno-oligomers, } \\
\text { mannobiose }\end{array}$ & \\
\hline Q72HW2 & T. termophilus & AA1 & Laccase & ABTS & 92 & 4.5 & $30.1^{*}$ & Monolignols & Miyazaki, 2005 \\
\hline Q47QG3 & T. fusca & AA10 & LPMO & Filter paper & 50 & 6.0 & ND & $\begin{array}{l}\text { C1/C4 oxidized } \\
\text { cellodextrins }\end{array}$ & Moser et al., 2008 \\
\hline A9XK88 & M. thermophilum & AA3/AA8 & $\mathrm{CDH}$ & cellobiose & 63 & 5.5 & $19.8^{*}$ & C1 oxidized cellobiose & $\begin{array}{l}\text { Zámockỷ et al., } \\
2008\end{array}$ \\
\hline B9MNB8 & C. bescii & $\mathrm{GH} 28$ & $\begin{array}{l}1,4-\alpha- \\
\text { galacturonidase }\end{array}$ & PGA & 72 & 5.2 & 384.6 & D-galacturonic acid & Chen et al., 2014 \\
\hline Q9WYR8 & T. maritima & & $\begin{array}{l}\text { Exo- } \\
\text { galacturonosidase }\end{array}$ & & 80 & 6.4 & 1170 & & Kluskens et al., 2005 \\
\hline Q6CZT4 & E. carotovora & PL-C & Pectate lyase & PGA & 40 & 8.3 & 1600 & $\begin{array}{l}\text { unsaturated } \\
\text { pectin-oligomers }\end{array}$ & Lei et al., 1987 \\
\hline Q07181 & G. fujikuroi & $\mathrm{GH} 28$ & Polygalacturonase & & ND & 5.0 & 500 & $\begin{array}{l}\text { pectin-oligomers } \\
\text { digalacturonic acid } \\
\text { D-galacturonic acid }\end{array}$ & Federici et al., 2001 \\
\hline P26509 & E. carotovora & & & & 40 & 5.5 & ND & & Saarilahti et al., 1990 \\
\hline P26214 & A. niger & & & & ND & 4.1 & 2000 & & Benen et al., 1996 \\
\hline GORUP7 & T. reesei & $\mathrm{GH} 11$ & $\begin{array}{l}\text { Endo-1,4- } \beta- \\
\text { xylanase }\end{array}$ & glucuronoxylan & 60 & 6.0 & ND & xylo-oligomers, D-xylose & $\begin{array}{l}\text { Saarelainen et al., } \\
1993\end{array}$ \\
\hline P62694 & & $\mathrm{GH} 7$ & Exo-glucanase & DNP-Lac & 50 & 5.0 & 0.72 & D-glucose & Becker et al., 2001 \\
\hline Q2F8H3 & & & Endo-glucanase & $\mathrm{CMC}$ & 55 & 5.0 & 220.2 & cellodextrins, cellobiose & Samanta et al., 2012 \\
\hline A0A223GCX3 & A. niger & $\mathrm{GH} 11$ & $\begin{array}{l}\text { Endo- } 1,4-\beta- \\
\text { xylanase }\end{array}$ & $\begin{array}{l}\text { oat spelts } \\
\text { xylan }\end{array}$ & 50 & 5.5 & 3881 & xylo-oligomers, D-xylose & $\begin{array}{l}\text { Levasseur et al., } \\
2005\end{array}$ \\
\hline ND & B. licheniformis & ND & $\alpha$-amylase & soluble starch & 90 & 9.0 & $77.1^{\star}$ & $\begin{array}{l}\text { Maltodextrins, } \\
\text { maltotriose }\end{array}$ & $\begin{array}{l}\text { Krishnan and } \\
\text { Chandra, } 1983\end{array}$ \\
\hline P29761 & $\begin{array}{l}\text { Clostridium } \\
\text { sp. }\end{array}$ & $\mathrm{GH} 15$ & Gluco-amylase & $\begin{array}{l}\text { Malto- } \\
\text { heptaose }\end{array}$ & ND & 4.5 & $66.3^{\star}$ & D-glucose & Ohnishi et al., 1992 \\
\hline Q7X3S6 & B. licheniformis & GH5 & Endoglucanase & $\mathrm{CMC}$ & 65 & ND & ND & cellodextrins, cellobiose & Liu et al., 2004 \\
\hline D1L8C5 & & GH9 & & & & & & & \\
\hline Q7X4S4 & & $\mathrm{GH} 12$ & & & & & & & \\
\hline P50401 & C. fimi & GH6 & Exo-glucanase & & 37 & 7.0 & $0.04^{*}$ & cellobiose, D-glucose & Meinke et al., 1994 \\
\hline P00722 & E. coli & $\mathrm{GH} 2$ & $\beta$-galactosidase & oNPG & ND & 7.0 & $256.9^{*}$ & D-galactose & $\begin{array}{l}\text { Sutendra et al., } \\
2007\end{array}$ \\
\hline Q45071 & B. subtilis & $\mathrm{GH} 43$ & Arabinofuranohydrolase & wheat bran & 45 & 5.6 & 3.2 & L-arabinose & Bourgois et al., 2007 \\
\hline O50152 & S. griseus & $\mathrm{GH} 19$ & Endochitinase & glycol chitin & ND & 6.0 & 10100 & chito-oligomers & Itoh et al., 2002 \\
\hline P07254 & S. marcescens & $\mathrm{GH} 18$ & Chitobiosidase & MU-chi2 & $\mathrm{N}$ & & 13.3 & Chitobiose & Brurberg et al., 1994 \\
\hline ND & T. emersonii & ND & $\mathrm{N}$-acetylglucosaminidase & MU-NAG & 75 & 5.0 & $534.3^{\star}$ & $\mathrm{N}$-acetylglucosamine & $\begin{array}{l}\text { O'Connell et al., } \\
2008\end{array}$ \\
\hline P00698 & $\begin{array}{l}\text { G. gallus } \\
\text { (egg) }\end{array}$ & $\mathrm{GH} 22$ & Lysozyme C & $\begin{array}{l}\text { M. luteus } \\
\text { suspension }\end{array}$ & 37 & 6.2 & 70400\# & Peptidoglycan oligomers & Chiang et al., 1993 \\
\hline P61626 & H. sapiens & $\mathrm{GH} 22$ & & & 40 & 6.5 & 201526\# & & Huang et al., 2002a \\
\hline
\end{tabular}

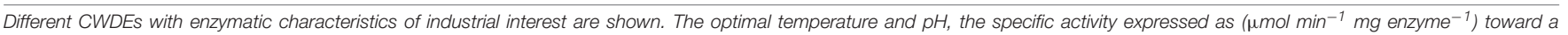

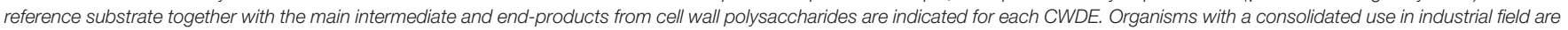

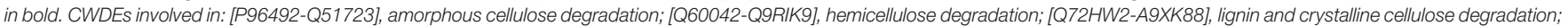

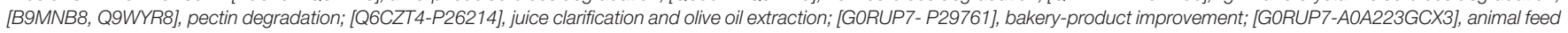

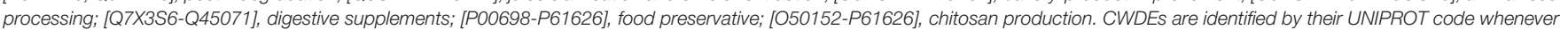

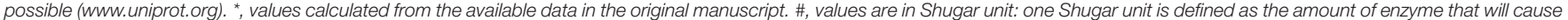

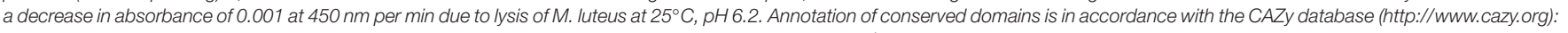

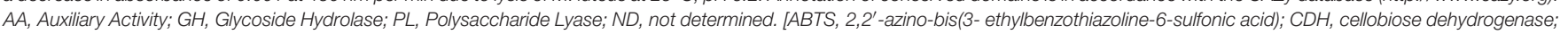

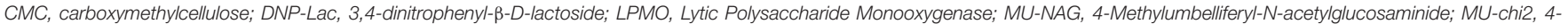

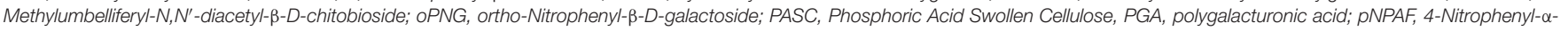
$L$-arabinofuranoside; pNPC, para-Nitrophenyl- $\beta-D$-cellobioside]. 
TABLE 2 | Biotechnological aspects of different CWDE-expressing biofactories.

\begin{tabular}{|c|c|c|c|c|c|c|c|c|c|}
\hline \multirow[t]{2}{*}{ Organisms } & \multicolumn{2}{|c|}{ Type of expression } & \multicolumn{3}{|c|}{ Production method } & \multirow[t]{2}{*}{$\begin{array}{l}\text { Potential CWDE } \\
\text { side effects }\end{array}$} & \multicolumn{2}{|c|}{$\begin{array}{l}\text { Post-translational } \\
\text { modifications }\end{array}$} & \multirow[t]{2}{*}{$\begin{array}{l}\text { CWDE } \\
\text { Secretion }\end{array}$} \\
\hline & $\begin{array}{l}\text { endogenous } \\
\text { CWDE Mix }\end{array}$ & HE & Type & $\begin{array}{l}\text { Annual biomass } \\
\text { productivity } \\
\mathrm{t}\left(\mathrm{ha}^{\star} \mathrm{y}\right)^{-1}\end{array}$ & $\begin{array}{l}\text { Biomass cost } \\
\left(€ \mathrm{~kg} \mathrm{DW}^{-1}\right)\end{array}$ & & $\begin{array}{l}\text { Disulphide } \\
\text { bridges }\end{array}$ & Glycosylation & \\
\hline $\begin{array}{l}\text { Bacteria e.g., } \\
\text { Bacillus, } \\
\text { Clostridium } \\
\text { Filamentous fungi } \\
\text { e.g., Trichoderma, } \\
\text { Aspergillus }\end{array}$ & YES & NO & $\begin{array}{l}\text { SF } \\
\text { SSF }\end{array}$ & NA & NA & NA & NA & NA & NA \\
\hline $\begin{array}{l}\text { E. coli } \\
\text { Yeasts e.g., } \\
\text { Kluyveromyces, } \\
\text { Pichia }\end{array}$ & NA & $N$ & HDF & & & YES & $\begin{array}{l}\text { NO } \\
\text { YES }\end{array}$ & $\begin{array}{l}\mathrm{NO} \\
\mathrm{YES}^{*}\end{array}$ & $\begin{array}{l}\text { YES } \\
\text { YES }\end{array}$ \\
\hline Plants N. tabacum & & $\begin{array}{l}\mathrm{C} \\
\mathrm{N}\end{array}$ & $\mathrm{F}$ & $8-8.1^{a}$ & $2^{a}$ & & & $\begin{array}{l}\text { NO } \\
\text { YES }\end{array}$ & NA \\
\hline $\begin{array}{l}\text { Microalgae e.g., } \\
\text { C. reinhardtii }\end{array}$ & & $\begin{array}{l}\mathrm{C} \\
\mathrm{N}\end{array}$ & PBR & $60^{b}$ & $3.8^{b}$ & & & $\begin{array}{l}\text { NO } \\
\text { YES }\end{array}$ & $\begin{array}{l}\text { NO } \\
\text { YES }\end{array}$ \\
\hline
\end{tabular}

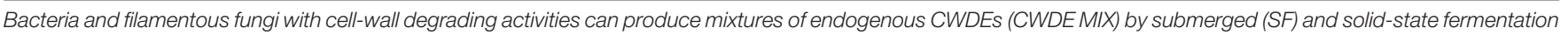

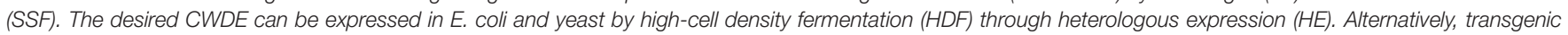

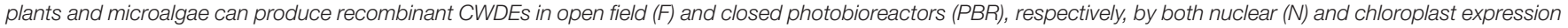

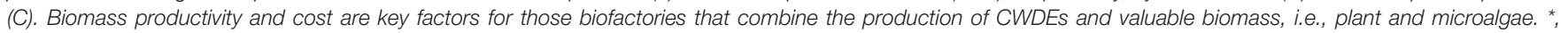

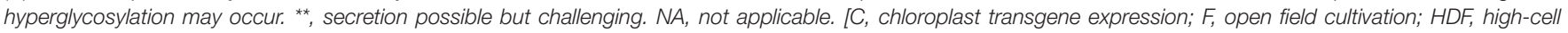

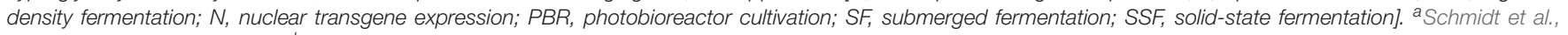
2019. Nat. Plants 5, 715-721. 'b Tredici et al., 2016. Algal Res 19, 253-263.

thus reducing the risk of overflow metabolism. On the opposite end, continuous fermentation requires an open growth system where sterilized solutions of nutrients are added in continuum to the bioreactor at the same rate at which the fermented medium is recovered from the system. This procedure results in a steady-rate production of the fermentation broth. In order to maintain the fermentation as efficient as possible, parameters such as temperature, $\mathrm{pH}$, oxygen and carbon dioxide levels must be continually monitored and adjusted.

Solid-state fermentation is used as an alternative to submerged fermentation. Solid-state fermentation occurs in the absence of free water, can usually reach greater volumetric productivity than submerged fermentation and is also characterized by an easier downstream process. In general, the solid-state fermentation involves a solid matrix (e.g., rice bran, wheat bran, steam exploded agricultural scraps) that is used as feed by the selected microbe. The substrate matrix is maintained for days at controlled temperature under constant or intermittent rotation allowing the growth of filamentous fungi under conditions that resemble their natural environment. Air flow rate must be monitored since it affects both the humidity and oxygen levels of the entire fermentation process. The use of sterilization procedures is not mandatory for solid-state fermentation except for the sterilization of the substrate at the beginning of the process. In general, solid-state fermentation has several advantages over submerged fermentation, such as the lower consumption of water and electricity, a lower waste efflux and a more concentrated enzymatic product (Zhuang et al., 2007). These three parameters impact the final cost of the enzyme-based product that will be cheaper than that obtained via submerged fermentation. At the end of the fermentation process, the CWDEs are separated from the residual materials by micro- and ultra-filtration procedures (Machado de Castro et al., 2010; Ferreira et al., 2018). Subsequently, the enzyme preparation will be concentrated at the desired level and stabilizing agents will be supplied to the preparation in order to increase the shelf-life of the enzyme-based product. Notably, if a high-value product is required as in the case of CWDEs for use in food processing and biomedical field, further purification procedures will be necessary in order to eliminate residual contaminants, thus increasing the final cost of the enzyme.

Pectinases, cellulases, xylanases, and $\alpha$-amylases are produced by microbial fermentation. By adjusting the carbon source used for inducing CWDE production, different enzymes can be secreted in the same fermentation broth; e.g., Aspergillus awamori, a fungus with GRAS (Generally Recognized As Safe) designation, secreted simultaneously cellulases, xylanases and $\alpha$-amylases when fed with the babassu cake, i.e., the residual material from babassu palm (Attalea speciosa) upon oil extraction (Machado de Castro et al., 2010).

One of the most relevant fungi for cellulase production is Trichoderma reesei. This filamentous fungus is employed as cellulase-producing bioreactor since 1980; a strain of this fungus named RUT-C30 was characterized by high level of cellulase 
production and, nowadays, is still exploited for the industrial production of cellulolytic enzymes such as cellobiohydrolases, endo- and exo-glucanases (Peterson and Nevalainen, 2012). The main weakness of $T$. reesei resides in the low level of secreted $\beta$-glucosidase, the enzyme responsible for the last step of cellulose degradation, i.e., the cleavage of cellobiose in two D-glucose units. Notably, cellobiose inhibits both endoglucanases and cellobiohydrolases by a product inhibition mechanism, thus pointing to the importance of $\beta$-glucosidase for an efficient enzymatic hydrolysis at industrial scale (Sørensen et al., 2013). In this regard, enzymatic blends from T. reesei often require supplementation with exogenous $\beta$-glucosidases. Important sources of pectinases, xylanases, $\alpha$-amilases and $\beta$ glucosidases are fungi belonging to the genus Aspergillus. Amongst them, Aspergillus niger plays a prominent role in the industrial production of pectinases and cellobiase, i.e., a type of $\beta$ glucosidase that specifically cleaves cellobiose (Singh et al., 1990; Reginatto et al., 2017). Expression of cellulases, pectinases and $\alpha$-amylases can be obtained by bacteria using submerged and solid-state fermentation as well. Amongst the many bacteria used as bioreactor, the most relevant in the production of cellulases and pectinases are B. licheniformis and B. subtilis. In addition to CWDEs from wild-type bacteria, recombinant CWDEs can be produced by $E$. coli through high cell density fermentation. Differently from other fermentation methods, high cell density fermentation is characterized by the highest operating costs (Ferreira et al., 2018). The advantage of using E. coli as bioreactor resides in five main factors: (i) rapid growth cycle, (ii) use of cheap growth media, (iii) capability of reaching high cell density through fermentation, (iv) possibility of using strains with low proteolytic activity, and (v) a thorough knowledge of its physiology and genetics. However, the translational machinery of bacteria cannot introduce post-translational modifications such as the formation of cytoplasmic disulphide bridges or glycosylation. Moreover, the poor ability of Gram-negative bacteria to secrete recombinant proteins in the culture medium implies expensive and time-consuming purification procedures, thus representing additional costs for their large-scale production (Table 2). To overcome this drawback, different approaches to enhance the secretion efficiency of recombinant CWDEs in E. coli have been developed. The yield of secreted recombinant cellulases and hemicellulases was increased by fusing the catalytic domain of the CWDE of interest to the CBM from another higher soluble cellulase (Murashima et al., 2003) or by reducing the temperature during expression in order to promote a correct protein folding (Song et al., 2012). Alternatively, expression hosts with higher secretion capabilities can be used such as the Grampositive bacteria B. subtilis (Morello et al., 2008) or Lactococcus lactis (Pohl and Harwood, 2010), and yeasts; the latter have higher secretion efficiency and can perform post-translational modifications. Many CWDEs have been successfully expressed as secreted proteins in Saccharomyces cerevisiae (MargollesClark et al., 1996; Haan et al., 2007, 2013; Van Zyl et al., 2010; Zhou et al., 2015), Kluyveromyces lactis and Pichia pastoris (Bey et al., 2011; Chen et al., 2011; Akbarzadeh et al., 2014; Table 2). Compared to other yeasts, $P$. pastoris and K. lactis glycosylate the secreted proteins at lesser extent, reducing the side-effects of unwanted hyperglycosylation. Yeast has been genetically improved to increase CWDE expression levels by the use of synthetic (Blazeck et al., 2013) and constitutive promoters (Haan et al., 2007; Wang et al., 2012), codon-optimized genes (Akcapinar et al., 2011) and selection of multicopy transformants (Yamada et al., 2011; Mellitzer et al., 2012).

\section{Plant and Microalgae as CWDE-Producing Biofactories}

Plant expression of CWDEs can be a valid alternative to microbial-based bio-factories. Plants are characterized by a high [productivity/production cost] ratio and consume atmospheric $\mathrm{CO}_{2}$ through photosynthesis, thus representing an eco-friendly expression system. Moreover, plants have GRAS status and are suitable for the production of high-value compounds at affordable costs. However, plant expression of CWDEs may have side-effects since CWDEs from lignocellulolytic fungi and bacteria are well-known pathogenicity factors whose accumulation can damage plant tissue and produce toxic effects (Benedetti et al., 2019a). Moreover, CWDEs can trigger plant defense responses independently of their enzyme activity, being recognized as dangerous non-host molecules through specific recognition mechanisms mediated by plant pattern recognition receptors (PRRs) at the apoplast/outer membrane interface (Poinssot et al., 2003; Ma et al., 2015; Zipfel, 2014; Choi and Klessig, 2016). In general, the expression of pectinases and cellulases in plants can be more insidious with respect to hemicellulases (Benedetti et al., 2015; Castiglia et al., 2016). It is worth mentioning that cell wall fragments derived from the partial breakdown of pectin and cellulose are powerful inducers of plant defense responses (Souza et al., 2017; De Lorenzo et al., 2019). Constitutively activated immunity may lead to detrimental effects due to the growth-defense trade off (Huot et al., 2014; Benedetti et al., 2015), resulting in impaired growth and eventually lethality. Recently, an enzymatic machinery capable of inactivating the elicitor activity of these cell wall derived fragments, namely oligogalacturonides and cellodextrins, has been identified (Benedetti et al., 2018b; Locci et al., 2019). Moreover, gene silencing events may also occur: the nuclear expression of the endoglucanase EGII from Acidothermus cellulolyticus in transgenic rice, for example, is suppressed during development from seedling to mature plant, resembling a self-defense mechanism (Li et al., 2019). Gene silencing is a well-known epigenetic mechanism in land plants that undermines the use of transgenic crops for field applications. Different plant expression strategies can be adopted to prevent these undesired event, such as compartmentalized expression and storage, inducible gene expression, expression of CWDEs with inducible activity (i.e., CWDEs with extreme $\mathrm{pH}$ - and temperature-dependent activities), use of hosts that are less sensitive to CWDEs (e.g., microalgae) or a combination of these strategies (e.g., chloroplast expression of hyperthermophilic CWDEs) (Benedetti et al., 2019a). The chloroplast expression of CWDEs in tobacco plants has several advantages: (i) high yields of recombinant protein since, unlike nuclear expression, chloroplast expression is not affected by gene silencing events, 
(ii) easier biocontainment of transgenes since the plastome is maternally inherited, thereby avoiding dispersion through the pollen by vertical gene transfer (Daniell, 2007; Adem et al., 2017), and (iii) the chloroplast expression of CWDEs in tobacco is well-documented, with a recent demonstration that CWDE production may be achieved in field condition without loss in enzyme yield for at least three consecutive growth cycles (Schmidt et al., 2019). Moreover, the chloroplast translational machinery catalyzes the formation of disulphide bridges, enabling the expression of eukaryotic CWDEs in their active form with no need of subsequent renaturation procedures (Taunt et al., 2018). However, the chloroplast system is not suitable for expressing cellulases that require glycosylation for proper activity and stability (Greene et al., 2015), although this trait could be favorable in other cases to avoid the undesired glycosylation of recombinant proteins. Tobacco can be grown in field with a production cost of $2 € \mathrm{~kg} \mathrm{DW} \mathrm{DW}^{-1}$ and an annual productivity of about $8.1 \mathrm{t}$ $\left(\text { ha* }{ }^{*}\right)^{-1}$ considering three growth cycle per year as the best achievable for tobacco plants under optimal latitude condition $\left(45^{\circ} \mathrm{N}\right.$ ) (Maksymowicz and Palmer, 1997; Foreman, 2006; Faè et al., 2017; Schmidt et al., 2019; Table 2). Even if a highdensity cultivation method has been reported for tobacco plants, transgenic plants expressing CWDEs have never been cultivated with this technology (Scott and Warren, 2012). Enzyme yields from transplastomic tobacco are very encouraging, on the other hand plants need arable land for their growth and longer times to produce significant amounts of recombinant proteins compared to microbes. In this regard, microalgae may represent a good alternative since they are characterized by faster growth rates and the capability of growing at higher $\mathrm{CO}_{2}$ concentration than land-plants. Moreover, microalgae can be cultivated in closed growth systems, i.e., photobioreactors, that can occupy waste lands, avoiding the subtraction of arable lands to the agri-food sector (Slade and Bauen, 2013; Tredici et al., 2016; Clippinger and Davis, 2019). Photobioreactors are closed environments where microalgae are exposed to continuous mixing, air supplementation, controlled light and temperature; it comes that algal productivity increases in photobioreactors as well as the production cost. Here, the productivity of microalgae, expressed as biomass produced per year, can reach $60 \mathrm{t}\left(\mathrm{y}^{*} \mathrm{ha}\right)^{-1}$, with a production cost of 3.2 to $3.8 € \mathrm{~kg} \mathrm{DW}^{-1}$ (Slade and Bauen, 2013; Tredici et al., 2016; Table 2). The production cost of photobioreactor-grown microalgae varies based on three main parameters: (i) the microalgal species of interest, (ii) the size, and (iii) the type of the photobioreactor used for the cultivation (Clippinger and Davis, 2019). The yield of CWDEs in the chloroplast of Chlamydomonas reinhardtii, i.e., the microalgae used as model organism, reached lower level compared to that of transplastomic tobacco plants (Faè et al., 2017; Richter et al., 2018); therefore, further optimization is still required for improving the expression stability and protein yield of CWDEs from microalgal-based biofactories (Benedetti et al., 2018a). However, it is worth noting that microalgae culturing may combine the expression of recombinant proteins to the production of valuable biomass (Benedetti et al., 2018a).

\section{YIELD AND COST ANALYSIS OF ENZYMES FROM DIFFERENT CWDE-PRODUCING BIOFACTORIES}

In this paragraph, the production costs of several CWDEs and productivity of different CWDE-producing biofactories are summarized in order to highlight strengths and weaknesses of each expression system. The limited number of established scientific reports concerning industrial CWDE-production reflects the need of a stronger integration of basic science with applied research. In the techno-economic analyses here reported (Zhuang et al., 2007; Machado de Castro et al., 2010; Humbird et al., 2011; Klein-Marcuschamer et al., 2011; Wilken and Nikolov, 2011; Ferreira et al., 2018), final values were obtained by projecting the results and production costs derived from pilotscale experiments to large-scale through different simulation software. The production costs are the same as those indicated in the manuscript from which they have been extrapolated, i.e., without normalizing the inflation rate over the years after the publication date. Conversion from United States $\$$ in $€$ was obtained by applying 0.9 as conversion factor. For the production analysis in tobacco plants, dry weight (DW) was considered as $10 \%$ fresh weight of the plant biomass. Enzyme activity of plant CWDEs was expressed in Units, i.e., the amount of the enzyme that catalyzes the conversion of one micromole of substrate per minute $\left(\mu \mathrm{mol} \mathrm{min}{ }^{-1}\right)$. Lysozyme activity was expressed in Shugar Units as described in Chiang et al. (1993) and Huang et al. (2002b). All the production costs and productivities as obtained from different CWDE-expressing bio-factories are summarized in Table 3.

\section{Yield and Cost Analysis of Microbial CWDE-Producing Biofactory}

Trichoderma reesei is a filamentous fungus employed as cellulaseproducing bioreactor secreting more than twenty different cellulolytic enzymes during fermentation. The cultivation of $T$. reesei can be carried out by submerged fermentation using both glucose and steam-exploded poplar as substrates for inducing the secretion of cellulases. By submerged fermentation, T. reesei produced up to $2.6 \mathrm{t}\left(\mathrm{y}^{*} \mathrm{~m}^{3}\right)^{-1}$ of cellulases (Humbird et al., 2011), with a production cost comprised between 3.82 and $9.12 € \mathrm{~kg}^{-1}$ (Humbird et al., 2011; Klein-Marcuschamer et al., 2011). It is worth noting that the commercial cellulase-based products are not only composed by cellulase(s). In general, other ingredients added on purpose and contaminants also contribute to the final weight of the cellulolytic blend. For example, some cellulolytic blends are composed by $15 \%(\mathrm{w} / \mathrm{v})$ of cellulases and $20 \%(\mathrm{w} / \mathrm{v})$ of glucose, the latter used as stabilizer to prolong the shelf-life of the enzymes (Rodrigues et al., 2015). By submerged fermentation, A. niger produced pectinases up to 9400 Units $\mathrm{L}^{-1}$, with an enzymatic yield of about $7.7 * 10^{5}$ Units per $\mathrm{kg}$ DW mycelium (Reginatto et al., 2017). A techno-economic analysis on the production of xylanases and $\alpha$-amylases by $A$. awamori is described in Machado de Castro et al. (2010). In this study, the large-scale production of $\alpha$-amylases and xylanases and, at 
TABLE 3 | Estimation of potential annual productivity and production costs of CWDEs obtained from different bio-factories.

\begin{tabular}{|c|c|c|c|c|c|c|c|}
\hline \multirow{2}{*}{ CWDE } & \multirow{2}{*}{ Organism } & \multirow{2}{*}{$\begin{array}{l}\text { Production } \\
\text { method }\end{array}$} & \multirow{2}{*}{$\begin{array}{l}\text { Annual enzyme productivity } \\
t\left(m^{3 *} y\right)^{-1} \mathbf{t}\left(\mathbf{h a}^{*} \mathbf{y}\right)^{-1}\end{array}$} & \multicolumn{2}{|c|}{ Production Cost } & \multirow{2}{*}{ Product value } & \multirow{2}{*}{ References } \\
\hline & & & & $€ \mathrm{~kg} \mathrm{DW}^{-1}$ & $U €^{-1}$ & & \\
\hline \multirow[t]{7}{*}{ Cellulase } & T. reesei & SF & 2.6 & 3.82 & ND & LOW-VALUE & Humbird et al., 2011 \\
\hline & & & ND & 9.12 & & & $\begin{array}{l}\text { Klein-Marcuschamer et al., } \\
2011\end{array}$ \\
\hline & C. thermocellum & & & 36.3 & & & Zhuang et al., 2007 \\
\hline & & SSF & & 14.1 & & & \\
\hline & $\begin{array}{l}\text { N. tabacum } \\
\text { (recombinant) }\end{array}$ & $\mathrm{C}$ & $1.13^{\star}$ & $14.3^{\star}$ & $0.06 \times 10^{5 *}$ & & Faè et al., 2017/This review \\
\hline & & & $0.32^{*}$ & $50^{*}$ & ND & & $\begin{array}{l}\text { Schmidt et al., 2019/This } \\
\text { review }\end{array}$ \\
\hline & & & $0.81^{*}$ & $20^{\star}$ & $246 \times 10^{5 *}$ & & $\begin{array}{l}\text { Verma et al., 2010/This } \\
\text { review }\end{array}$ \\
\hline \multirow[t]{2}{*}{$\beta$-glucosidase } & $\begin{array}{l}\text { N. tabacum } \\
\text { (recombinant) }\end{array}$ & & $0.46^{\star}$ & $35^{\star}$ & $73 \times 10^{5 *}$ & & $\begin{array}{l}\text { Castiglia et al., 2016/This } \\
\text { review }\end{array}$ \\
\hline & $\begin{array}{l}\text { E. coli } \\
\text { (recombinant) }\end{array}$ & HDF & 0.88 & 284 & ND & & Ferreira et al., 2018 \\
\hline \multirow[t]{2}{*}{ Xylanase } & $\begin{array}{l}\text { N. tabacum } \\
\text { (recombinant) }\end{array}$ & C & $0.12^{\star}$ & $132^{\star}$ & $8.1 \times 10^{5 *}$ & & $\begin{array}{l}\text { Castiglia et al., 2016/This } \\
\text { review }\end{array}$ \\
\hline & A. awamori & SSF & ND & 9.36 & $0.26 \times 10^{5}$ & & $\begin{array}{l}\text { Machado de Castro et al., } \\
2010\end{array}$ \\
\hline \multirow[t]{2}{*}{ Pectate Lyase } & $\begin{array}{l}\text { N. tabacum } \\
\text { (recombinant) }\end{array}$ & C & $0.85^{\star}$ & $18.9^{\star}$ & $1.3 \times 10^{5 *}$ & & $\begin{array}{l}\text { Verma et al., 2010/This } \\
\text { review }\end{array}$ \\
\hline & & & $1.14^{\star}$ & $14.2^{\star}$ & $1.6 \times 10^{5 *}$ & & \\
\hline EWL & G. gallus & $\begin{array}{l}\text { hen } \\
\text { egg-white }\end{array}$ & NA & $326^{*}$ & $21.5 \times 10^{7 \star}$ & & $\begin{array}{l}\text { Chiang et al., 1993/This } \\
\text { review }\end{array}$ \\
\hline HUL & $\begin{array}{l}\text { O. sativa } \\
\text { (recombinant) }\end{array}$ & $R G$ & $0.048^{*}$ & $150^{\star}$ & $133 \times 10^{7 *}$ & & $\begin{array}{l}\text { Huang et al., 2002a,b/This } \\
\text { review }\end{array}$ \\
\hline \multirow[t]{2}{*}{ EWL } & $\begin{array}{l}\text { K. lactis } \\
\text { (recombinant) }\end{array}$ & $\mathrm{HDF}+\mathrm{P}$ & ND & NA & $0.14 \times 10^{7 \star}$ & HIGH-VALUE & Huang and Demirci, 2009 \\
\hline & egg-white & $\begin{array}{l}\text { egg-white } \\
+\mathrm{P}\end{array}$ & NA & $479^{\star}+1845$ & $3 \times 10^{7 *}$ & & $\begin{array}{l}\text { Wilken and Nikolov, } \\
2011 / \text { This review }\end{array}$ \\
\hline HUL & $R G$ & $R G+P$ & & $273^{\star}+1971$ & $8.9 \times 10^{7 *}$ & & \\
\hline
\end{tabular}

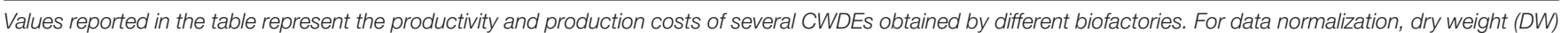

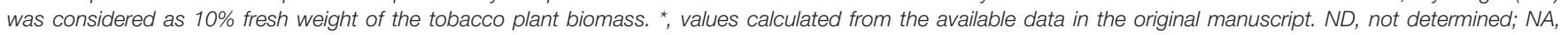

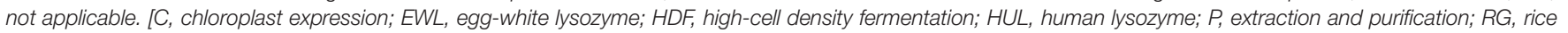
grains; SF, submerged fermentation; SSF, solid-state fermentation].

lower extent, of cellulases, was carried out by solid-state fermentation using babassu cake as substrate. The highest levels of production were reached upon 6-7 days of solidstate fermentation with values of 250.000- and 85.000-Units $\mathrm{kg}^{-1} \mathrm{DW}$ for xylanase and amylase activity, respectively. With respect to other filamentous fungi, Aspergillus awamori is characterized by the GRAS designation, positively impacting the production cost of the enzymes because the fermented substrate can be sold as feed, thus reducing the total costs of the entire process. According to this possibility, the initial production cost of the CWDE-based product $(30.74 € \mathrm{~kg}$ $\mathrm{DW}^{-1}$ ) could be reduced to $9.36 € \mathrm{~kg} \mathrm{DW}^{-1}$ upon selling the fermented babassu cake, reaching the same production cost of enzymatic blends from $T$. reesei. Production of a recombinant $\beta$-glucosidase in $E$. coli by high cell density fermentation reached a productivity of $0.88 \mathrm{t}\left(\mathrm{y} \mathrm{m}^{3}\right)^{-1}$ and a production cost of $284 € \mathrm{Kg}^{-1}$ using a fermenter of $100 \mathrm{~m}^{3}$. At the end of the process, the $\beta$-glucosidase was available in a concentrated form (15 $\mathrm{g}$ enzyme $\left.\mathrm{L}^{-1}\right)$ and ready to be supplemented in cellulolytic blends. Notably, the addition of $\beta$-glucosidase in cellulolytic blends in the ratio $0.9: 10\left[\mathrm{w}_{\beta}\right.$ -glucosidase: $\left.\mathrm{w}_{\text {cellulases }}\right]$ would increase the final price of the enzymatic blend up to $137 \%$ (Ferreira et al., 2018). A technoeconomic analysis concerning the production of thermostable cellulases by thermophilic bacteria was described in Zhuang et al. (2007). Here, the thermostable cellulases were produced by Clostridium thermocellum, a thermophilic bacterium with optimal growth at $60^{\circ} \mathrm{C}$, using both the submerged and solidstate fermentation. The main characteristic of this thermophilic bacterium resides in the capability of producing cellulosomes, multi-enzyme complexes characterized by more than twenty different catalytic domains (Gold and Martin, 2007). Submerged and solid-state fermentation allowed the production of cellulases with a cost ranging from 14.1 to $36.3 € \mathrm{Kg}^{-1}$ for those obtained by solid-state and submerged fermentation, respectively. B. subtilis is also used as a pectinase-producer organism. Submerged 
fermentation of $B$. subtilis reached a maximal yield of pectinolytic activity around 66100 Units L $^{-1}$ (Oumer and Abate, 2018), about 7-times higher than that obtained from $A$. niger by using the same fermentation method (Reginatto et al., 2017); to date, technoeconomic assessments of pectinase-expressing bio-factories have not been reported despite the high number of studies concerning the production of pectinases through different fermentation procedures (Garg et al., 2016).

\section{Yield and Cost Analysis of Plant CWDE-Producing Biofactory}

Cell wall degrading enzymes production is generally confined to the chloroplast, thus avoiding the interaction with both PRRs and cell wall polysaccharides and preventing the formation of oligosaccharidic elicitors. Nonetheless, chloroplast expression of CWDEs preserved plant fitness at variable extents (Verma et al., 2010; Castiglia et al., 2016; Schmidt et al., 2019). Chloroplast expression of the hyper-thermostable cellulase from Sulfolobus solfataricus resulted in tobacco plants with stunted growth and pale-green phenotype despite the expression was compartmentalized and the enzyme activity was inducible by high temperature (Castiglia et al., 2016). Notably, transplastomic tobacco expressing the $\beta$-glucosidase from Pyrococcus furiosus accumulated $14.5 * 10^{6}$ Units $\mathrm{kg} \mathrm{DW}^{-1}$ plant biomass and a theoretical enzyme yield of $57 \mathrm{~g} \mathrm{~kg} \mathrm{DW}^{-1}$ in accordance with the specific activity of the enzyme (255 Units $\mathrm{mg}^{-1}$ ). In this case, the enzyme productivity was $0.46 \mathrm{t}\left(\mathrm{ha}^{*} \mathrm{y}\right)^{-1}$ while the production cost of the enzyme was $35 € \mathrm{~kg}^{-1}$ in the tobacco leaf wet basis. Surprisingly, the specific activity of $\beta$-glucosidase from tobacco chloroplast was higher than that reported for the native enzyme from $P$. furiosus, i.e., 750 vs 446 Units $\mathrm{mg}^{-1}$ as determined at $90^{\circ} \mathrm{C}$ using $p$-nitrophenylglucoside as substrate (Kengen et al., 1993; Castiglia et al., 2016). However, the transplastomic expression of $\beta$-glucosidase from $P$. furiosus affected the plant development at variable extent, resulting in both dwarf and wild-type like plants. Similar yield was obtained for the xylanase from Alicyclobacillus acidocaldarius; in this case, plant accumulated $1.6^{*} 10^{6}$ Units $\mathrm{kg} \mathrm{DW}^{-1}$ plant biomass and a theoretical enzyme yield of $15.2 \mathrm{~g} \mathrm{~kg} \mathrm{DW}^{-1}$ in accordance with the specific activity of the enzyme (105 Units $\left.\mathrm{mg}^{-1}\right)$. Here, the enzyme productivity was $0.12 \mathrm{t}\left(\mathrm{ha}^{*} \mathrm{y}\right)^{-1}$ while the production cost of the xylanase was $132 € \mathrm{~kg}^{-1}$ in the tobacco leaf wet basis. In Faè et al. (2017), transplastomic tobacco plants accumulated $140 \mathrm{~g} \mathrm{~kg}$ $\mathrm{DW}^{-1}$ of the cellulase CelK1 from Paenibacillus; notably, plants grew without morphological defect. The enzyme productivity was $1.13 \mathrm{t}\left(\mathrm{ha}^{*} \mathrm{y}\right)^{-1}$, while the enzyme cost was $14.3 €$ $\mathrm{kg}^{-1}$ in the tobacco leaf wet basis. However, the enzyme activity in the leaf tissue was very low $\left(12^{*} 10^{3}\right.$ Units $\mathrm{kg}$ $\mathrm{DW}^{-1}$ ) indicating that CelK1 was not very active, with a theoretical specific activity of 0.08 Units $\mathrm{mg}^{-1}$. A further study on the production of CWDEs from transplastomic tobacco plants in field-grown condition is described in Schmidt et al. (2019). According to this study, plants stably accumulated the thermostable endoglucanase Cel6A from Thermobifida fusca over different growth cycles reaching a maximum yield of $40 \mathrm{~g}$
$\mathrm{DW}^{-1}$ plant biomass. The enzyme productivity was $0.32 \mathrm{t}$ $\left(\text { ha* }{ }^{*}\right)^{-1}$, while the production cost of the enzyme was $50 €$ $\mathrm{kg}^{-1}$ in the tobacco leaf wet basis. A comparison of activity would also be necessary, since data on Cel6A activity are not reported in this study. Healthy tobacco plants that accumulated high yield of active endoglucanase and two different pectin lyases are described in Verma et al. (2010). The enzyme productivities ranged from 0.81 to $1.14 \mathrm{t}\left(\mathrm{ha}^{*} \mathrm{y}\right)^{-1}$ for the endoglucanase celD from $C$. thermocellum and pectin lyase PelD from Erwinia carotovora, respectively, with an enzyme production cost comprised between 14.2 and $20 € \mathrm{~kg}^{-1}$ in the tobacco leaf wet basis.

All these results taken together suggest that plant-CWDE interaction is not easily predictable and therefore, it should be evaluated case by case. As an alternative, photosynthetic hosts less sensitive to plant CWDE could be used, such as the microalga $C$. reinhardtii. Transplastomic expression of endoglucanases has been obtained in C. reinhardtii although the enzyme yield was lower than that from transplastomic tobacco plants (Faè et al., 2017; Richter et al., 2018). The lack of a clear phytotoxic effect in $C$. reinhardtii toward plant CWDEs could be ascribed to the algal cell wall composition, mainly protein rather than polysaccharidic (Imam et al., 1985), along with a different host-microbe coevolutionary adaptation. In terms of yield, the chloroplast of $C$. reinhardtii may accumulate recombinant protein up to at most $5 \%(\mathrm{w} / \mathrm{w})$ of the total soluble proteins (Manuell et al., 2007), corresponding to $1.2 \%$ (w/w) of the algal biomass (Rasala et al., 2010). Cultivation of microalgae can be achieved at high productivity in closed growth systems such as photobioreactors; amongst the several techno-economic analyses performed on such topics, the best-case scenarios were reported by Slade and Bauen (2013) and Tredici et al. (2016). Considering these parameters, C. reinhardtii may theoretically produce a hypothetical CWDE up to $12 \mathrm{~g} \mathrm{~kg}^{-1} \mathrm{DW}$ of microalgal biomass, with an enzyme productivity of $0.72 \mathrm{t}\left(\mathrm{ha} \mathrm{H}^{*}\right)^{-1}$ and enzyme production costs ranging from 267 to $317 € \mathrm{~kg}^{-1}$ in the algal biomass wet basis.

\section{Case Study: Lysozyme, a High Value CWDE With Many Industrial Applications}

Lysozyme isoforms from hen egg-white and human are the most relevant in biotechnological field; human lysozyme (HUL) is preferable over egg-white lysozyme (EWL) due to the higher specific activity (HUL: 201526 Units $\mathrm{mg}^{-1}$ vs EWL: 70400 Units $\mathrm{mg}^{-1}$ ) (Chiang et al., 1993; Huang et al., 2002b) and to the "safer" designation since HUL, unlike EWL, does not cause allergic reactions in humans (Ercan and Demirci, 2016). Notably, the use of lysozyme in medicine implies further purification procedures and, therefore, higher production costs compared to other CWDEs with application as low-value products (e.g., biofuels, paper industry). Due to its hydrolysing activity toward the cell wall of bacteria and filamentous fungi, expression in such organisms is unfeasible. Lysozyme is commonly obtained from hen egg-white upon extraction and purification. The amount of 
lysozyme is around $0.15 \mathrm{~g}$ per egg (Abeyrathne et al., 2013); given that the average weight of an egg is $65 \mathrm{~g}$ and that the production cost of a single egg is $0.05 €$ in a conventional hen-housing system, one kilogram of eggs contains about $2.3 \mathrm{~g}$ of lysozyme with a production cost of $0.75 €$ (Matthews and Sumner, 2015). Based on these estimations, the production cost of EWL is around $326 € \mathrm{~kg}^{-1}$ in the egg wet basis. Wilken and Nikolov estimated that the purification procedure for obtaining EWL with a purity greater than $94 \%$ had an approximate cost of $1845 € \mathrm{~kg}^{-1}$ (Wilken and Nikolov, 2011); such procedure was characterized by a purification yield of $68 \%$ indicating that about 600 kilograms of eggs are required to obtain $1 \mathrm{~kg}$ of pure lysozyme. According to this scenario, the production cost of a high-purity lysozyme preparation from egg-white is $2295 € \mathrm{~kg}^{-1}\left(3 \times 10^{7}\right.$ Units $\left.€^{-1}\right)$. However, many lysozymebased products such as those used in food processing are characterized by lower costs (expressed as $€ \mathrm{~kg}^{-1}$ product) because the real lysozyme content does not correspond to the weight of the product. In these cases, customers should always refer to the Units per gram of product rather than to the sole weight. In this regard, it is worth noting that the enzymatic Units of lysozyme can be defined through diverse methods, making the comparison between different lysozymebased products rather uncertain.

In addition to the hen egg-white, other important sources of lysozyme are recombinant yeast and rice. Lysozyme can be purified upon production by Kluiveromyces lactis through highcell density fermentation with higher costs, i.e., $0.14 \times 10^{7}$ Units $€^{-1}$ (Huang and Demirci, 2009). Importantly, the use of yeasts for expressing CWDEs with potential applications in the biomedical field requires great caution since the secreted CWDEs could be hyper-glycosylated. Glycosylated proteins from yeast-based biofactory cannot be used in food processing and medicine due to the possibility of triggering allergic reactions in humans. Fortunately, the amino acid sequence of lysozyme is not characterized by the presence of potential $N$-glycosylation sites. The most relevant bio-factory of HUL is transgenic rice (Oryza sativa). The expression level of lysozyme in the rice grain reaches $6 \mathrm{~g} \mathrm{~kg}^{-1} \mathrm{DW}$ and therefore, 1 kilogram of recombinant lysozyme is contained in about $167 \mathrm{~kg}$ of rice grains (Huang et al., 2002a). Bearing in mind that the annual rice productivity can reach about $8 \mathrm{t}\left(\mathrm{ha}^{*} \mathrm{y}\right)^{-1}$ under the best climate and irrigation conditions ${ }^{2}$ and the production cost of recombinant grain flour is $0.9 € \mathrm{~kg}^{-1} \mathrm{DW}$, i.e., five-fold higher than the common grain flour (Wilken and Nikolov, 2011), then the annual productivity of HUL from transgenic rice is around $0.048 \mathrm{t}\left(\mathrm{ha}^{*} \mathrm{y}\right)^{-1}$ with a production cost of $150 € \mathrm{~kg}^{-1}$ in the rice flour wet basis. Wilken and Nikolov estimated that the purification procedure for obtaining HUL from recombinant rice with a purity greater than $91 \%$ had an approximate cost of $1971 € \mathrm{~kg}^{-1}$. This procedure was characterized by a purification yield of $55 \%$ indicating that about $304 \mathrm{~kg}$ of rice grains are required to obtain $1 \mathrm{~kg}$ of pure lysozyme. According to this information, the production cost of pure HUL from recombinant rice is $2244 € \mathrm{~kg}^{-1}\left(8.9 \times 10^{7}\right.$ Units $\left.€^{-1}\right)$.

\footnotetext{
${ }^{2}$ http://ricepedia.org/rice-as-a-crop/rice-productivity
}

\section{CONCLUSION}

To date, the enzymatic conversion of cell-wall materials into fermentable sugars is characterized by low-efficiency and high operating costs. For enzymatic hydrolysis to be economically feasible in large scale productions, the optimization of CWDEproducing biofactories is necessary to reduce enzymes cost and improve the degradation activity of CWDE-blends. Improvement of degradation can be obtained by including enzymes with novel and/or improved catalytic activities (e.g., CWDEs from Extremophiles) to the existing enzymatic mixtures. Wild-type microbes secrete a wide array of CWDEs during fermentation and are therefore bio-factories of first choice when a mixture of CWDEs is preferable over the production of a single enzyme, with production costs ranging from 4 to $36 € \mathrm{~kg}^{-1}$ enzymatic product depending on the microbial species used (Table 3). However, if a single CWDE is required, the heterologous expression can be a better option. Several factors must be considered for establishing heterologous expression of CWDEs, such as the enzyme's characteristics, possible toxicity or side-effects for the host organism and the target application field, that may or may not require high enzyme purity. Factors such as the secretion ability of yeast or the ability to form disulphide bridges can have a significant impact on the expression of CWDEs (Table 2). On the other hand, yeasts may hyper-glycosylate the recombinant protein with possible alteration of the enzyme activity or possible allergenicity in humans; the latter point is crucial for those CWDEs that are planned to be used in nutraceutical or biomedical fields (Table 2). In this context, chloroplast expression represents a good alternative since plants are GRAS organism. Moreover, the translation machinery of the chloroplast can direct the synthesis of proteins with correct folding and disulphide bridge formation, thus allowing the expression of different categories of CWDEs. Tobacco chloroplast allowed to obtain high amount of different CWDEs with production costs ranging from 14 to $132 € \mathrm{~kg}^{-1}$ enzyme, depending on the type of CWDE. As an example, a recombinant $\beta$-glucosidase was obtained from transplastomic tobacco plants at a production cost eight times lower than in E. coli; however, to produce 0.9 tonnes of $\beta$-glucosidase in tobacco may require two years and one hectare of arable land, whereas the same amount may be obtained just in two weeks using a $26 \mathrm{~m}^{3}$ fermenter for $E$. coli (Table 3). Taking into account that (i) CWDEs are used to degrade lignocellulosic biomass at industrial scale with a costeffective enzyme loading from 0.5 to $1.5 \%$ (w/w) (application sheets of Cellic CTec2, HTec2-Enzymes, and Cellic CTec3 for hydrolysis of lignocellulosic materials; Herrero Garcia et al., 2019), (ii) the annual production of lignocellulosic waste from agriculture residues is 4.6 billion tonnes (Dahmen et al., 2019), and (iii) the annual production of cellulases and pectinases from transplastomic tobacco can be estimated around 1 tonne CWDE per hectare (Table 3), it comes that 23 to 69 million hectares (1.6 to $4.9 \%$ world's arable lands) would be required to cultivate enough transplastomic tobacco plants for satisfying such enzyme request. Thus, a high product demand may force out of the market plant-based biofactories since arable lands are in competition with the agri-food production. In this perspective, 
microalgae could represent the missing link between microbialand plant-based biofactory since they are characterized by a faster growth rate than plants and offer the possibility of combining the expression of recombinant proteins with the production of valuable biomass. However, transgenic expression in microalgae still requires further optimization.

It is worth noting that several CWDEs are perceived as pathogenicity factor by plants and therefore, their expression should be evaluated case by case. On the other hand, plants can express CWDEs that are toxic for microbes, as in the case of human lysozyme that has been produced in transgenic rice. Similarly, since an efficient chitinase-expressing biofactory is still missing, the chloroplast expression of a hyper-thermostable chitinase in tobacco could be advantageous, because unlike what occurs in microorganisms, this type of CWDE is not toxic for plant health.

Special attention must be paid to the quality of the expressed "CWDE/enzymatic product"; in some cases, the recombinant CWDE can display altered activity likely due to post-translational modifications and other issues related to the heterologous expression (Table 2), or the CWDE pool produced by wild type microbes can be characterized by a low enzyme content per $\mathrm{kg}$ of product. In all these cases, both the enzyme production costs and enzyme loading in industrial practices must refer to the Enzyme Units rather than the protein amounts (Table 3).

In conclusion, wild-type microbes are the biofactory of first choice to express CWDEs for industrial processes requiring the action of multiple CWDEs (e.g., lignocellulose degradation), while plants are more indicated to express

\section{REFERENCES}

Abdel-Tawwab, M., Razek, N. A., and Abdel-Rahman, A. M. (2019). Immunostimulatory effect of dietary chitosan nanoparticles on the performance of Nile tilapia, Oreochromis niloticus (L.). Fish Shellfish Immunol. 88, 254-258. doi: 10.1016/j.fsi.2019.02.063

Abeyrathne, E. D. N. S., Lee, H. Y., and Ahn, D. U. (2013). Egg white proteins and their potential use in food processing or as nutraceutical and pharmaceutical agents-A review. Poult. Sci. 92, 3292-3299. doi: 10.3382/ps.2013-03391

Adem, M., Beyene, D., and Feyissa, T. (2017). Recent achievements obtained by chloroplast transformation. Plant Methods 13:30. doi: 10.1186/s13007-0170179- 1

Ahmed, A., and Bibi, A. (2018). Fungal cellulase; production and applications: minireview. Int. J. Health Life Sci. 4, 19-36. doi: 10.20319/lijhls.2018.41.1936

Akbarzadeh, A., Ranaei Siadat, S. O., Motallebi, M., Zamani, M. R., Barshan Tashnizi, M., and Moshtaghi, S. (2014). Characterization and high-level expression of acidic endoglucanase in Pichia pastoris. Appl. Biochem. Biotechnol. 172, 2253-2265. doi: 10.1007/s12010-0130672-6

Akcapinar, G. B., Gul, O., and Sezerman, U. (2011). Effect of codon optimization on the expression of Trichoderma reesei endoglucanase 1 in Pichia pastoris. Biotechnol. Prog. 27, 1257-1263. doi: 10.1002/btpr.663

Alcorlo, M., Martínez-Caballero, S., Molina, R., and Hermoso, J. A. (2017). Carbohydrate recognition and lysis by bacterial peptidoglycan hydrolases. Curr. Opin. Struct. Biol. 44, 87-100. doi: 10.1016/j.sbi.2017.01.001

Baumann, M. J., Borch, K., and Westh, P. (2011). Xylan oligosaccharides and cellobiohydrolase I (TrCel7A) interaction and effect on activity. Biotechnol. Biofuels 4:45. doi: 10.1186/1754-6834-4-45

Bayer, E. A., Chanzy, H., Lamed, R., and Shoham, Y. (1998). Cellulose, cellulases and cellulosomes. Curr. Opin. Struct. Biol. 8, 548-557. doi: 10.1016/S0959440X(98)80143-7 specific CWDEs, especially when the expression in microbial host is challenging and the application field will imply the use of high value products (e.g., food processing, medical field). In this context, microalgae have a great but still unexploited potential.

In the last decades, the potential of different CWDEexpressing biofactories has been widely investigated, contributing to define the present scenario. Thus, the type and the characteristics of the expressed CWDE, the enzyme cost and productivity, the latter in relation with the market demand of the enzyme, are parameters that determine the effectiveness of the selected biofactory.

\section{AUTHOR CONTRIBUTIONS}

MG, MB, and BM identified patterns and trends in the literature and designed the structure of the review. MG, GG, and MB prepared the tables and figures. All the authors contributed to the search for relevant literature, carried out a critical analysis of the literature, discussed together, and wrote the manuscript. All authors read and approved the final manuscript.

\section{FUNDING}

This work was supported by co-financing of the European Union - PON Research and Innovation 2014-2020, grant ARS01_00881 “ORIGAMI”.

Becker, D., Braet, C., Brumer, H., Claeyssens, M., Divne, C., Fagerström, B. R., et al. (2001). Engineering of a glycosidase Family 7 cellobiohydrolase to more alkaline $\mathrm{pH}$ optimum: the $\mathrm{pH}$ behaviour of Trichoderma reesei Cel7A and its E223S/ A224H/L225V/T226A/D262G mutant. Biochem. J. 356, 19-30.

Benedetti, M., Locci, F., Gramegna, G., Sestili, F., and Savatin, D. V. (2019a). Green production and biotechnological applications of cell wall lytic enzymes. Appl. Sci. 9:5012. doi: 10.3390/app9235012

Benedetti, M., Pontiggia, D., Raggi, S., Cheng, Z., Scaloni, F., Ferrari, S., et al. (2015). Plant immunity triggered by engineered in vivo release of oligogalacturonides, damage-associated molecular patterns. Proc. Natl. Acad. Sci. U.S.A. 112, 5533-5538. doi: 10.1073/pnas.1504154112

Benedetti, M., Vecchi, V., Barera, S., and Dall'Osto, L. (2018a). Biomass from microalgae: the potential of domestication towards sustainable biofactories. Microb. Cell Fact. 17:173. doi: 10.1186/s12934-018-1019-3

Benedetti, M., Vecchi, V., Betterle, N., Natali, A., Bassi, R., and Dall'Osto, L. (2019b). Design of a highly thermostable hemicellulose-degrading blend from Thermotoga neapolitana for the treatment of lignocellulosic biomass. J. Biotechnol. 296, 42-52. doi: 10.1016/j.jbiotec.2019.03.005

Benedetti, M., Verrascina, I., Pontiggia, D., Locci, F., Mattei, B., De Lorenzo, G., et al. (2018b). Four Arabidopsis berberine bridge enzyme-like proteins are specific oxidases that inactivate the elicitor-active oligogalacturonides. Plant J. 94, 260-273. doi: 10.1111/tpj.13852

Benen, J. A. E., Kester, H. C. M., Parenicová, L., and Visser, J. (1996). Kinetics and mode of action of Aspergillus niger polygalacturonases. Prog. Biotechnol. $14,221-230$.

Bey, M., Berrin, J. G., Poidevin, L., and Sigoillot, J. C. (2011). Heterologous expression of Pycnoporus cinnabarinus cellobiose dehydrogenase in Pichia pastoris and involvement in saccharification processes. Microb. Cell Fact. 10:113. doi: 10.1186/1475-2859-10-113

Binod, P., Sindhu, R., Janu, K. U., and Pandey, A. (2019). "Hydrolysis of cellulosic and hemicellulosic biomass," in Biofuels: Alternative Feedstocks and 
Conversion Processes for the Production of Liquid and Gaseous Biofuels, eds M. J. Taherzadeh, K. Bolton, and A. Pandey (Cambridge, MA: Academic Press), 447-460. doi: 10.1016/B978-0-12-816856-1.00019-1

Bissaro, B., Isaksen, I., Vaaje-Kolstad, G., Eijsink, V. G. H., and Røhr, A. K. (2018). How a lytic polysaccharide monooxygenase binds crystalline chitin. Biochemistry 57, 1893-1906. doi: 10.1021/acs.biochem.8b00138

Blazeck, J., Reed, B., Garg, R., Gerstner, R., Pan, A., Agarwala, V., et al. (2013). Generalizing a hybrid synthetic promoter approach in Yarrowia lipolytica. Appl. Microbiol. Biotechnol. 97, 3037-3052. doi: 10.1007/s00253-0124421-5

Bok, J. D., Yernool, D. A., and Eveleigh, D. E. (1998). Purification, characterization, and molecular analysis of thermostable cellulases CelA and CelB from Thermotoga neapolitana. Appl. Environ. Microbiol. 64, 4774-4781.

Bourgois, T. M., Van Craeyveld, V., Van Campenhout, S., Courtin, C. M., Delcour, J. A., Robben, J., et al. (2007). Recombinant expression and characterization of XynD from Bacillus subtilis subsp. subtilis ATCC 6051: a GH 43 arabinoxylan arabinofuranohydrolase. Appl. Microbiol. Biotechnol. 75, 1309-1317. doi: 10. 1007/s00253-007-0956-2

Brenelli, L., Squina, F. M., Felby, C., and Cannella, D. (2018). Laccase-derived lignin compounds boost cellulose oxidative enzymes AA9. Biotechnol. Biofuels 11:10. doi: 10.1186/s13068-017-0985-8

Brurberg, M. B., Eijsink, V. G. H., and Nes, I. F. (1994). Characterization of a chitinase gene (chiA) from Serratia marcescens BJL200 and one-step purification of the gene product. FEMS Microbiol. Lett. 124, 399-404. doi: 10.1111/j.1574-6968.1994.tb07315.x

Burton, R. A., Gidley, M. J., and Fincher, G. B. (2010). Heterogeneity in the chemistry, structure and function of plant cell walls. Nat. Chem. Biol. 6, 724-732. doi: $10.1038 /$ nchembio.439

Caffall, K. H., and Mohnen, D. (2009). The structure, function, and biosynthesis of plant cell wall pectic polysaccharides. Carbohydr. Res. 344, 1879-1900. doi: 10.1016/j.carres.2009.05.021

Castiglia, D., Sannino, L., Marcolongo, L., Ionata, E., Tamburino, R., De Stradis, A., et al. (2016). High-level expression of thermostable cellulolytic enzymes in tobacco transplastomic plants and their use in hydrolysis of an industrially pretreated Arundo donax L. biomass. Biotechnol. Biofuels 9:154. doi: 10.1186/ s13068-016-0569-z

Cauchie, H.-M. (2002). Chitin production by arthropods in the hydrosphere. Hydrobiologia 470, 63-95. doi: 10.1023/A:1015615819301

Chen, P., Fu, X., Ng, T. B., and Ye, X. Y. (2011). Expression of a secretory $\beta$ glucosidase from Trichoderma reesei in Pichia pastoris and its characterization. Biotechnol. Lett. 33, 2475-2479. doi: 10.1007/s10529-011-0724-3

Chen, Y., Sun, D., Zhou, Y., Liu, L., Han, W., Zheng, B., et al. (2014). Cloning, expression and characterization of a novel thermophilic polygalacturonase from Caldicellulosiruptor bescii DSM 6725. Int. J. Mol. Sci. 15, 5717-5729. doi: 10. 3390/ijms15045717

Chiang, B. H., Su, C. K., Tsai, G. J., and Tsao, G. T. (1993). Egg white lysozyme purification by ultrafiltration and affinity chromatography. J. Food Sci. 58, 303-306. doi: 10.1111/j.1365-2621.1993.tb04261.x

Choi, H. W., and Klessig, D. F. (2016). DAMPs, MAMPs, and NAMPs in plant innate immunity. BMC Plant Biol. 16:232. doi: 10.1186/s12870-016-0921-2

Choi, J., Kim, K.-T., Jeon, J., and Lee, Y.-H. (2013). Fungal plant cell wall-degrading enzyme database: a platform for comparative and evolutionary genomics in fungi and Oomycetes. BMC Genomics 14:S7. doi: 10.1186/1471-2164-14-S5-S7

Clippinger, J. N., and Davis, R. E. (2019). Techno-Economic Analysis for the Production of Algal Biomass via Closed Photobioreactors: Future Cost Potential Evaluated Across a Range of Cultivation System Designs. Golden, CO: National Renewable Energy Lab (NREL).

Dahmen, N., Lewandowski, I., Zibek, S., and Weidtmann, A. (2019). Integrated lignocellulosic value chains in a growing bioeconomy: Status quo and perspectives. GCB Bioenergy 11, 107-117.

Dall'Osto, L., Cazzaniga, S., Guardini, Z., Barera, S., Benedetti, M., Mannino, G., et al. (2019). Combined resistance to oxidative stress and reduced antenna size enhance light-to-biomass conversion efficiency in Chlorella vulgaris cultures. Biotechnol. Biofuels 12:221. doi: 10.1186/s13068-019-1566-9

Daniell, H. (2007). Transgene containment by maternal inheritance: effective or elusive? Proc. Natl. Acad. Sci. U. S. A. 104, 6879-6880. doi: 10.1073/pnas. 0702219104

De Lorenzo, G., Ferrari, S., Giovannoni, M., Mattei, B., and Cervone, F. (2019). Cell wall traits that influence plant development, immunity, and bioconversion. Plant J. 97, 134-147. doi: 10.1111/tpj.14196
Desvaux, M., Candela, T., and Serror, P. (2018). Surfaceome and proteosurfaceome in parietal monoderm bacteria: focus on protein cell-surface display. Front. Microbiol. 9:100. doi: 10.3389/fmicb.2018.00100

Dimarogona, M., Topakas, E., and Christakopoulos, P. (2012). Cellulose degradation by oxidative enzymes. Comput. Struct. Biotechnol. J. 2:e201209015. doi: $10.5936 /$ csbj.201209015

Dörr, T., Moynihan, P. J., and Mayer, C. (2019). Editorial: bacterial cell wall structure and dynamics. Front. Microbiol. 10:2051. doi: 10.3389/fmicb.2019. 02051

Eibinger, M., Ganner, T., Bubner, P., Rošker, S., Kracher, D., Haltrich, D., et al. (2014). Cellulose surface degradation by a lytic polysaccharide monooxygenase and its effect on cellulase hydrolytic efficiency. J. Biol. Chem. 289, 35929-35938. doi: 10.1074/jbc.M114.602227

Eijsink, V. G. H., Petrovic, D., Forsberg, Z., Mekasha, S., Røhr, A. K., Várnai, A., et al. (2019). On the functional characterization of lytic polysaccharide monooxygenases (LPMOs). Biotechnol. Biofuels 12:58. doi: 10.1186/s13068019-1392-0

Ercan, D., and Demirci, A. (2016). Recent advances for the production and recovery methods of lysozyme. Crit. Rev. Biotechnol. 36, 1078-1088. doi: 10. 3109/07388551.2015.1084263

Faè, M., Accossato, S., Cella, R., Fontana, F., Goldschmidt-Clermont, M., Leelavathi, S., et al. (2017). Comparison of transplastomic Chlamydomonas reinhardtii and Nicotiana tabacum expression system for the production of a bacterial endoglucanase. Appl. Microbiol. Biotechnol. 101, 4085-4092. doi: 10.1007/s00253-017-8164-1

Federici, L., Caprari, C., Mattei, B., Savino, C., Di Matteo, A., De Lorenzo, G., et al. (2001). Structural requirements of endopolygalacturonase for the interaction with PGIP (polygalacturonase-inhibiting protein). Proc. Natl. Acad. Sci. U.S.A. 98, 13425-13430. doi: 10.1073/pnas.231473698

Ferreira, R. G., Azzoni, A. R., and Freitas, S. (2018). Techno-economic analysis of the industrial production of a low-cost enzyme using E. coli: the case of recombinant $\beta$-glucosidase. Biotechnol. Biofuels 11:81. doi: 10.1186/s13068018-1077-0

Fong, D., and Hoemann, C. D. (2018). Chitosan immunomodulatory properties: perspectives on the impact of structural properties and dosage. Future Sci. OA 4:FSO225. doi: 10.4155/fsoa-2017-0064

Foreman, L. (2006). Tobacco Production Costs and Returns in 2004. Washington, DC: USDA.

Gao, D., Haarmeyer, C., Balan, V., Whitehead, T. A., Dale, B. E., and Chundawat, S. P. (2014). Lignin triggers irreversible cellulase loss during pretreated lignocellulosic biomass saccharification. Biotechnol. Biofuels 7:175. doi: 10.1186/ s13068-014-0175-x

Garg, G., Singh, A., Kaur, A., Singh, R., Kaur, J., and Mahajan, R. (2016). Microbial pectinases: an ecofriendly tool of nature for industries. 3 Biotech 6:47. doi: 10.1007/s13205-016-0371-4

Gerken, H. G., Donohoe, B., and Knoshaug, E. P. (2013). Enzymatic cell wall degradation of Chlorella vulgaris and other microalgae for biofuels production. Planta 237, 239-253. doi: 10.1007/s00425-012-1765-0

Ghonemy, D. H. E. (2014). Microbial amidases and their industrial applications: a review. J. Med. Microb. Diagn. 4:173. doi: 10.4172/2161-0703.1000173

Gibson, D. M., King, B. C., Hayes, M. L., and Bergstrom, G. C. (2011). Plant pathogens as a source of diverse enzymes for lignocellulose digestion. Curr. Opin. Microbiol. 14, 264-270. doi: 10.1016/j.mib.2011.04.002

Glass, N. L., Schmoll, M., Cate, J. H. D., and Coradetti, S. (2013). Plant cell wall deconstruction by Ascomycete fungi. Annu. Rev. Microbiol. 67, 477-498. doi: 10.1146/annurev-micro-092611-150044

Gold, N. D., and Martin, V. J. J. (2007). Global view of the Clostridium thermocellum cellulosome revealed by quantitative proteomic analysis. J. Bacteriol. 189, 6787-6795. doi: 10.1128/JB.00882-07

Gow, N. A. R., Latge, J.-P., and Munro, C. A. (2017). The fungal cell wall: structure, biosynthesis, and function. Microbiol. Spectr. 5, 1-25. doi: 10.1128/ microbiolspec.FUNK-0035-2016

Greene, E. R., Himmel, M. E., Beckham, G. T., and Tan, Z. (2015). Glycosylation of cellulases, engineering better enzymes for biofuels. Adv. Carbohydr. Chem. Biochem. 72, 63-112. doi: 10.1016/bs.accb.2015.08.001

Haan, R. D., Kroukamp, H., Van Zyl, J. H. D., and Van Zyl, W. H. (2013). Cellobiohydrolase secretion by yeast: current state and prospects for improvement. Process Biochem. 48, 1-12.

Haan, R. D., McBride, J. E., La Grange, D. C., Lynd, L. R., and Van Zyl, W. H. (2007). Functional expression of cellobiohydrolases in Saccharomyces cerevisiae 
towards one-step conversion of cellulose to ethanol. Enzym. Microb. Technol. 40, 1291-1299.

Harman, G. E. (1993). Chitinolytic enzymes of Trichoderma harzianum: purification of chitobiosidase and endochitinase. Phytopathology 83, 313-318. doi: 10.1094/Phyto-83-313

Herlihey, F. A., and Clarke, A. J. (2017). "Controlling autolysis during flagella insertion in gram-negative bacteria," in Protein Reviews. Advances in Experimental Medicine and Biology, ed. M. Z. Atassi (Singapore: Springer), 41-56. doi: 10.1007/5584_2016_52

Herrero Garcia, N., Benedetti, M., and Bolzonella, D. (2019). Effects of enzymes addition on biogas production from anaerobic digestion of agricultural biomasses. Waste Biomass Valor. 10, 3711-3722. doi: 10.1007/s12649-01900698-7

Höfte, H., and Voxeur, A. (2017). Plant cell walls. Curr. Biol. 27, R865-R870. doi: $10.1016 /$ j.cub.2017.05.025

Höltje, J.-V. (1995). From growth to autolysis: the murein hydrolases in Escherichia coli. Arch. Microbiol. 164, 243-254. doi: 10.1007/BF02529958

Hu, J., Tian, D., Renneckar, S., and Saddler, J. N. (2018). Enzyme mediated nanofibrillation of cellulose by the synergistic actions of an endoglucanase, lytic polysaccharide monooxygenase (LPMO) and xylanase. Sci. Rep. 8:3195. doi: 10.1038/s41598-018-21016-6

Huang, E. L., and Demirci, A. (2009). Enhanced human lysozyme production by Kluyveromyces lactis. Food Bioprocess Technol. 2, 222-228. doi: 10.1007/s11947008-0062-1

Huang, J., Nandi, S., Wu, L., Yalda, D., Bartley, G., Rodriguez, R., et al. (2002a). Expression of natural antimicrobial human lysozyme in rice grains. Mol. Breed. 10, 83-94. doi: 10.1023/A:1020355511981

Huang, J., Wu, L., Yalda, D., Adkins, Y., Kelleher, S. L., Crane, M., et al. (2002b). Expression of functional recombinant human lysozyme in transgenic rice cell culture. Transgenic Res. 11, 229-239. doi: 10.1023/A:1015663706259

Humbird, D., Davis, R., Tao, L., Kinchin, C., Hsu, D., Aden, A., et al. (2011). Process Design and Economics for Biochemical Conversion of Lignocellulosic Biomass to Ethanol: Dilute-Acid Pretreatment and Enzymatic Hydrolysis of Corn Stover. Golden, CO: National Renewable Energy Lab.

Huot, B., Yao, J., Montgomery, B. L., and He, S. Y. (2014). Growth-defense tradeoffs in plants: a balancing act to optimize fitness. Mol. Plant 7, 1267-1287. doi: $10.1093 / \mathrm{mp} / \mathrm{ssu} 049$

Imam, S. H., Buchanan, M. J., Shin, H. C., and Snell, W. J. (1985). The Chlamydomonas cell wall: characterization of the wall framework. J. Cell Biol. 101, 1599-1607. doi: 10.1083/jcb.101.4.1599

Irazoki, O., Hernandez, S. B., and Cava, F. (2019). Peptidoglycan muropeptides: release, perception, and functions as signaling molecules. Front. Microbiol. 10:500. doi: 10.3389/fmicb.2019.00500

Itoh, Y., Kawase, T., Nikaidou, N., Fukada, H., Mitsutomi, M., Watanabe, T., et al. (2002). Functional analysis of the chitin-binding domain of a family 19 chitinase from Streptomyces griseus HUT6037: substrate-binding affinity and cis-dominant increase of antifungal function. Biosci. Biotechnol. Biochem. 66, 1084-1092.

Jayasekara, S., and Ratnayake, R. (2019). "Microbial cellulases: an overview and applications," in Cellulose, eds A. Rodríguez Pascual and M. E. Eugenio Martín (London: IntechOpen), doi: 10.5772/intechopen.84531

Jönsson, L. J., and Martín, C. (2016). Pretreatment of lignocellulose: formation of inhibitory by-products and strategies for minimizing their effects. Bioresour. Technol. 199, 103-112. doi: 10.1016/j.biortech.2015.10.009

Juge, N. (2006). Plant protein inhibitors of cell wall degrading enzymes. Trends Plant Sci. 11, 359-367.

Jujjavarapu, S. E., and Dhagat, S. (2019). Evolutionary trends in industrial production of $\alpha$-amylase. Recent Pat. Biotechnol. 13, 4-18. doi: 10.2174/ 2211550107666180816093436

Kalunke, R. M., Tundo, S., Benedetti, M., Cervone, F., De Lorenzo, G., and D'Ovidio, R. (2015). An update on polygalacturonase-inhibiting protein (PGIP), a leucine-rich repeat protein that protects crop plants against pathogens. Front. Plant Sci. 6:146. doi: 10.3389/fpls.2015. 00146

Kang, X., Kirui, A., Muszyǹski, A., Widanage, M. C. D., Chen, A., Azadi, P., et al. (2018). Molecular architecture of fungal cell walls revealed by solid-state NMR. Nat. Commun. 9:2747. doi: 10.1038/s41467-018-05199-0
Karamanos, Y. (1997). Endo-N-acetyl- $\beta$-D-glucosaminidases and their potential substrates?: structure/function relationships. Res. Microbiol. 148, 661-671. doi: 10.1016/S0923-2508(99)80065-5

Keegstra, K. (2010). Plant cell walls. Plant Physiol. 154, 483-486. doi: 10.1104/pp. 110.161240

Kengen, S. W. M., Luesink, E. J., Stams, A. J. M., and Zehnder, A. J. B. (1993). Purification and characterization of an extremely thermostable beta-glucosidase from the hyperthermophilic archaeon Pyrococcus furiosus. Eur. J. Biochem. 213, 305-312. doi: 10.1111/j.1432-1033.1993.tb17763.x

Klein-Marcuschamer, D., Oleskowicz-Popiel, P., Simmons, B. A., and Blanch, H. W. (2011). The challenge of enzyme cost in the production of lignocellulosic biofuels. Biotechnol. Bioeng. 109, 1083-1087. doi: 10.1002/bit.24370

Kluskens, L. D., van Alebeek, G.-J. W. M., Walther, J., Voragen, A. G. J., de Vos, W. M., and van der Oost, J. (2005). Characterization and mode of action of an exopolygalacturonase from the hyperthermophilic bacterium Thermotoga maritima. FEBS J. 272, 5464-5473. doi: 10.1111/j.1742-4658.2005.04935.x

Krishnan, T., and Chandra, A. K. (1983). Purification and characterization of alpha-Amylase from Bacillus licheniformis CUMC305. Appl. Environ. Microbiol. 46, 430-437.

Kumar, M., Jeon, J., Choi, J., and Kim, S.-R. (2018). Rapid and efficient genetic transformation of the green microalga Chlorella vulgaris. J. Appl. Phycol. 30, 1735-1745. doi: 10.1007/s10811-018-1396-3

Kumar, S., Muthuvelayudham, R., and Viruthagiri, T. (2014). Statistical optimization-based production of L-glutaminase (Ec 3.5.1.2) by Streptomyces griseus under submerged fermentation. Int. J. ChemTech Res. 6, 1489-1498.

Laurent, C. V. F. P., Breslmayr, E., Tunega, D., Ludwig, R., and Oostenbrink, C. (2019). Interaction between cellobiose dehydrogenase and lytic polysaccharide monooxygenase. Biochemistry 58, 1226-1235. doi: 10.1021/acs.biochem. $8 \mathrm{~b} 01178$

Lavigne, R., Briers, Y., Hertveldt, K., Robben, J., and Volckaert, G. (2004). Identification and characterization of a highly thermostable bacteriophage lysozyme. Cell. Mol. Life Sci. 61, 2753-2759. doi: 10.1007/s00018-004-4301-y

Lei, S. P., Lin, H. C., Wang, S. S., Callaway, J., and Wilcox, G. (1987). Characterization of the Erwinia carotovora pelB gene and its product pectate lyase. J. Bacteriol. 169, 4379-4383. doi: 10.1128/JB.169.9.4379-4383.1987

Levasseur, A., Asther, M., and Record, E. (2005). Overproduction and characterization of xylanase B from Aspergillus niger. Can. J. Microbiol. 51, 177-183.

Li, Y., Sun, H., Fan, C., Hu, H., Wu, L., Jin, X., et al. (2019). Overproduction of fungal endo- $\beta$-1,4-glucanase leads to characteristic lignocellulose modification for considerably enhanced biomass enzymatic saccharification and bioethanol production in transgenic rice straw. Cellulose 26, 8249-8261. doi: 10.1007/ s10570-019-02500-2

Li, Y., Sun, Z., Ge, X., and Zhang, J. (2016). Effects of lignin and surfactant on adsorption and hydrolysis of cellulases on cellulose. Biotechnol. Biofuels 9:20. doi: 10.1186/s13068-016-0434-0

Liu, Y., Zhang, J., Liu, Q., Zhang, C., and Ma, Q. (2004). Molecular cloning of novel cellulase genes cel9A and cel12A from Bacillus licheniformis GXN151 and synergism of their encoded polypeptides. Curr. Microbiol. 49, 234-238. doi: 10.1007/s00284-004-4291-x

Locci, F., Benedetti, M., Pontiggia, D., Citterico, M., Caprari, C., Mattei, B., et al. (2019). An Arabidopsis berberine bridge enzyme-like protein specifically oxidizes cellulose oligomers and plays a role in immunity. Plant J. 98, 540-554. doi: $10.1111 /$ tpj.14237

Loose, J. S. M., Forsberg, Z., Kracher, D., Scheiblbrandner, S., Ludwig, R., Eijsink, V. G. H., et al. (2016). Activation of bacterial lytic polysaccharide monooxygenases with cellobiose dehydrogenase. Protein Sci. 25, 2175-2186. doi: $10.1002 /$ pro. 3043

Ma, Y., Han, C., Chen, J., Li, H., He, K., Liu, A., et al. (2015). Fungal cellulase is an elicitor but its enzymatic activity is not required for its elicitor activity: fungal cellulase as an elicitor. Mol. Plant Pathol. 16, 14-26. doi: 10.1111/mpp.12156

Machado de Castro, A. M., Carvalho, D. F., Freire, D. M. G., Castilho, L., and dos, R. (2010). Economic analysis of the production of amylases and other hydrolases by Aspergillus awamori in solid-state fermentation of babassu cake. Enzyme Res. 2010:576872. doi: 10.4061/2010/576872

Maksymowicz, B., and Palmer, G. (1997). Tobacco Management: Optimizing Profits. Lexington, KY: University of Kentucky. 
Malgas, S., Kwanya Minghe, V. M., and Pletschke, B. I. (2019). The effect of hemicellulose on the binding and activity of cellobiohydrolase I, Cel7A, from Trichoderma reesei to cellulose. Cellulose 27, 781-797. doi: 10.1007/ s10570-019-02848-5

Manuell, A. L., Beligni, M. V., Elder, J. H., Siefker, D. T., Tran, M., Weber, A., et al. (2007). Robust expression of a bioactive mammalian protein in Chlamydomonas chloroplast. Plant Biotechnol. J. 5, 402-412. doi: 10.1111/j. 1467-7652.2007.00249.x

Margolles-Clark, E., Tenkanen, M., Nakari-Setaälä;, T., and Penttilä, M. (1996). Cloning of genes encoding alpha- $\mathrm{L}-$ arabinofuranosidase and beta-xylosidase from Trichoderma reesei by expression in Saccharomyces cerevisiae. Appl. Environ. Microbiol. 62, 3840-3846.

Martínez, A. T., Ruiz-Dueñas, F. J., Camarero, S., Serrano, A., Linde, D., Lund, H., et al. (2017). Oxidoreductases on their way to industrial biotransformations. Biotechnol. Adv. 35, 815-831. doi: 10.1016/j.biotechadv.2017.06.003

Matthews, W. A., and Sumner, D. A. (2015). Effects of housing system on the costs of commercial egg production. Poult. Sci. 94, 552-557. doi: 10.3382/ps/peu011

Meinke, A., Gilkes, N. R., Kwan, E., Kilburn, D. G., Warren, R. A. J., and Miller, R. C. (1994). Cellobiohydrolase A (CbhA) from the cellulolytic bacterium Cellulomonas fimi is a beta-1,4-exoceilobiohydrolase analogous to Trichoderma reesei CBH II. Mol. Microbiol. 12, 413-422. doi: 10.1111/j.1365-2958.1994. tb01030.x

Mellitzer, A., Weis, R., Glieder, A., and Flicker, K. (2012). Expression of lignocellulolytic enzymes in Pichia pastoris. Microb. Cell Fact. 11:61. doi: 10. 1186/1475-2859-11-61

Miyazaki, K. (2005). A hyperthermophilic laccase from Thermus thermophilus HB27. Extremophiles 9, 415-425. doi: 10.1007/s00792-005-0458-z

Mohammadzadeh, R., Zamani, M., Motallebi, M., Norouzi, P., Jourabchi, E., Benedetti, M., et al. (2012). Agrobacterium tumefaciens-mediated introduction of polygalacturonase inhibiting protein 2 gene (PvPGIP2) from Phaseolus vulgaris into sugar beet (Beta vulgaris L.). Aust. J. Crop Sci. 6, 1290-1297.

Momeni, M. H., Ubhayasekera, W., Sandgren, M., Ståhlberg, J., and Hansson, H. (2015). Structural insights into the inhibition of cellobiohydrolase Cel7A by xylo-oligosaccharides. FEBS J. 282, 2167-2177. doi: 10.1111/febs.13265

Morello, E., Bermuìdez-Humaraìn, L. G., Llull, D., Solè̀, V., Miraglio, N., Langella, P., et al. (2008). Lactobacillus lactis, an efficient cell factory for recombinant protein production and secretion. J. Mol. Microbiol. Biotechnol. 14, 48-58.

Moser, F., Irwin, D., Chen, S., and Wilson, D. B. (2008). Regulation and characterization of Thermobifida fusca carbohydrate-binding module proteins E7 and E8. Biotechnol. Bioeng. 100, 1066-1077. doi: 10.1002/bit.21856

Müller, G., Chylenski, P., Bissaro, B., Eijsink, V. G. H., and Horn, S. J. (2018). The impact of hydrogen peroxide supply on LPMO activity and overall saccharification efficiency of a commercial cellulase cocktail. Biotechnol. Biofuels 11:209. doi: 10.1186/s13068-018-1199-4

Murashima, K., Kosugi, A., and Doi, R. H. (2003). Solubilization of cellulosomal cellulases by fusion with cellulose- binding domain of noncellulosomal cellulase engd from Clostridium cellulovorans. Proteins Struct. Funct. Bioinform. 50, $620-628$.

Nandakumar, R., Yoshimune, K., Wakayama, M., and Moriguchi, M. (2003). Microbial glutaminase: biochemistry, molecular approaches and applications in the food industry. J. Mol. Catal. B Enzym. 23, 87-100. doi: 10.1016/S1381$1177(03) 00075-4$

Nipkow, A., Shen, G. J., and Zeikus, J. G. (1989). Continuous production of thermostable beta-amylase with Clostridium thermosulfurogenes: effect of culture conditions and metabolite levels on enzyme synthesis and activity. Appl. Environ. Microbiol. 55, 689-694.

Obeng, E. M., Adam, S. N. N., Budiman, C., Ongkudon, C. M., Maas, R., and Jose, J. (2017). Lignocellulases: a review of emerging and developing enzymes, systems, and practices. Bioresour. Bioprocess. 4 ,

O'Connell, E., Murray, P., Piggott, C., Hennequart, F., and Tuohy, M. (2008). Purification and characterization of a $\mathrm{N}$-acetylglucosaminidase produced by Talaromyces emersonii during growth on algal fucoidan. J. Appl. Phycol. 20, 557-565. doi: 10.1007/s10811-007-9291-3

Ohnishi, H., Kitamura, H., Minowa, T., Sakai, H., and Ohta, T. (1992). Molecular cloning of a glucoamylase gene from a thermophilic Clostridium and kinetics of the cloned enzyme. Eur. J. Biochem. 207, 413-418. doi: 10.1111/j.1432-1033. 1992.tb17064.x

Oku, T., and Ishikawa, K. (2006). Analysis of the hyperthermophilic chitinase from Pyrococcus furiosus: activity toward crystalline chitin. Biosci. Biotechnol. Biochem. 70, 1696-1701. doi: 10.1271/bbb.60031
Oumer, O. J., and Abate, D. (2018). Comparative studies of pectinase production by Bacillus subtilis strain Btk 27 in submerged and solidstate fermentations. Biomed Res. Int. 2018:1514795. doi: 10.1155/2018/151 4795

Parenti, G., Meroni, G., and Ballabio, A. (1997). The sulfatase gene family. Curr. Opin. Genet. Dev. 7, 386-391. doi: 10.1016/S0959-437X(97)80153-0

Park, J. I., Kent, M. S., Datta, S., Holmes, B. M., Huang, Z., Simmons, B. A., et al. (2011). Enzymatic hydrolysis of cellulose by the cellobiohydrolase domain of CelB from the hyperthermophilic bacterium Caldicellulosiruptor saccharolyticus. Bioresour. Technol. 102, 5988-5994. doi: 10.1016/j.biortech. 2011.02.036

Parker, K. N., Chhabra, S., Lam, D., Snead, M. A., Mathur, E. J., and Kelly, R. M. (2001). $\beta$-Mannosidase from Thermotoga species. Methods Enzymol. 330, 238-246. doi: 10.1016/S0076-6879(01)30379-8

Payne, C. M., Knott, B. C., Mayes, H. B., Hansson, H., Himmel, M. E., Sandgren, M., et al. (2015). Fungal cellulases. Chem. Rev. 115, 1308-448. doi: 10.1021/ cr500351c

Peterson, R., and Nevalainen, H. (2012). Trichoderma reesei RUT-C30 - thirty years of strain improvement. Microbiology 158, 58-68. doi: 10.1099/mic.0.054031-0

Pillai, C. K. S., Paul, W., and Sharma, C. P. (2009). Chitin and chitosan polymers: chemistry, solubility and fiber formation. Prog. Polym. Sci. 34, 641-678. doi: 10.1016/j.progpolymsci.2009.04.001

Pohl, S., and Harwood, C. R. (2010). Heterologous protein secretion by Bacillus species. Adv. Clin. Chem. 73, 1-25.

Poinssot, B., Vandelle, E., Bentéjac, M., Adrian, M., Levis, C., Brygoo, Y., et al. (2003). The Endopolygalacturonase 1 from Botrytis cinerea activates grapevine defense reactions unrelated to its enzymatic activity. Mol. Plant Microbe Interact. 16, 553-564. doi: 10.1094/MPMI.2003.16.6.553

Ragland, S. A., and Criss, A. K. (2017). From bacterial killing to immune modulation: recent insights into the functions of lysozyme. PLoS Pathog. 13:e1006512. doi: 10.1371/journal.ppat.1006512

Rasala, B. A., Muto, M., Lee, P. A., Jager, M., Cardoso, R. M. F., Behnke, C. A., et al. (2010). Production of therapeutic proteins in algae, analysis of expression of seven human proteins in the chloroplast of Chlamydomonas reinhardtii: production of therapeutic proteins in algae. Plant Biotechnol. J. 8, 719-733. doi: 10.1111/j.1467-7652.2010.00 503.x

Reginatto, C., Rossi, C., Miglioranza, B. G., dos Santos, M., Meneghel, L., Silveira, M. M., et al. (2017). Pectinase production by Aspergillus niger LB-02-SF is influenced by the culture medium composition and the addition of the enzyme inducer after biomass growth. Process Biochem. 58, 1-8. doi: 10.1016/j.procbio. 2017.04.018

Richter, L. V., Yang, H., Yazdani, M., Hanson, M. R., and Ahner, B. A. (2018). A downstream box fusion allows stable accumulation of a bacterial cellulase in Chlamydomonas reinhardtii chloroplasts. Biotechnol. Biofuels 11:133. doi: 10.1186/s13068-018-1127-7

Ridley, B. L., O’Neill, M. A., and Mohnen, D. (2001). Pectins: structure, biosynthesis, and oligogalacturonide-related signaling. Phytochemistry 57, 929967. doi: 10.1016/S0031-9422(01)00113-3

Rinaudo, M. (2006). Chitin and chitosan: properties and applications. Prog. Polym. Sci. 31, 603-632. doi: 10.1016/j.progpolymsci.2006.06.001

Rodrigues, A. C., Haven, M. Ø., Lindedam, J., Felby, C., and Gama, M. (2015). Celluclast and Cellic§CTec2: saccharification/fermentation of wheat straw, solid-liquid partition and potential of enzyme recycling by alkaline washing. Enzyme Microb. Technol. 79-80, 70-77. doi: 10.1016/j.enzmictec.2015. 06.019

Rudall, K. M., and Kenchington, W. (1973). The chitin system. Biol. Rev. 48, 597-633. doi: 10.1111/j.1469-185X.1973.tb01570.x

Saarelainen, R., Paloheimo, M., Fagerström, R., Suominen, P. L., and Nevalainen, K. M. H. (1993). Cloning, sequencing and enhanced expression of the Trichoderma reesei endoxylanase II (pI 9) gene xln2. Mol. Gen. Genet. 24, 497-503. doi: 10.1007/BF00279891

Saarilahti, H. T., Heino, P., Pakkanen, R., Kalkkinen, N., Palva, I., and Palva, E. T. (1990). Structural analysis of the pehA gene and characterization of its protein product, endopolygalacturonase, of Erwinia carotovora subspecies carotovora. Mol. Microbiol. 4, 1037-1044. doi: 10.1111/j.1365-2958.1990.tb0 0676.x

Saini, J. K., Saini, R., and Tewari, L. (2015). Lignocellulosic agriculture wastes as biomass feedstocks for second-generation bioethanol production: concepts and recent developments. 3 Biotech 5, 337-353. doi: 10.1007/s13205-014-0246-5 
Saini, R., Saini, H. R., and Dahiya, A. (2017). Amylases: characteristics and industrial applications. J. Pharmacogn. Phytochem. 6, 1865-1871.

Sajith, S., Priji, P., Sreedevi, S., and Benjamin, S. (2016). An overview on fungal cellulases with an industrial perspective. J. Nutr. Food Sci. 6:461. doi: 10.4172/ 2155-9600.1000461

Salyers, A. A., Palmer, J. K., and Wilkins, T. D. (1977). Laminarinase (betaglucanase) activity in Bacteroides from the human colon. Appl. Environ. Microbiol. 33, 1118-1124.

Samanta, S., Basu, A., Halder, U. C., and Sen, S. K. (2012). Characterization of Trichoderma reesei endoglucanase II expressed heterologously in Pichia pastoris for better biofinishing and biostoning. J. Microbiol. 50, 518-525. doi: 10.1007/ s12275-012-1207-5

Sandhu, S. K., Mathur, A., Gupta, R., Puri, S. K., and Adsul, M. (2018). "Cellulosic biomass-hydrolyzing enzymes," in Waste to Wealth, eds R. R. Singhania, R. A. Agarwal, R. P. Kumar, and R. K. Sukumaran (Singapore: Springer), 441-456. doi: 10.1007/978-981-10-7431-8_19

Sarmiento, F., Peralta, R., and Blamey, J. M. (2015). Cold and hot extremozymes: industrial relevance and current trends. Front. Bioeng. Biotechnol. 3:148. doi: 10.3389/fbioe.2015.00148

Sathish, T., Kezia, D., Bramhachari, P. V., and Prakasham, R. S. (2018). Multiobjective based superimposed optimization method for enhancement of 1 -glutaminase production by Bacillus subtilis RSP-GLU. Karbala Int. J. Mod. Sci. 4, 50-60. doi: 10.1016/j.kijoms.2017.10.006

Scheller, H. V., and Ulvskov, P. (2010). Hemicelluloses. Annu. Rev. Plant Biol. 61, 263-289. doi: 10.1146/annurev-arplant-042809-112315

Schmidt, J. A., McGrath, J. M., Hanson, M. R., Long, S. P., and Ahner, B. A. (2019). Field-grown tobacco plants maintain robust growth while accumulating large quantities of a bacterial cellulase in chloroplasts. Nat. Plants 5, 715-721. doi: 10.1038/s41477-019-0467-z

Scholz, M. J., Weiss, T. L., Jinkerson, R. E., Jing, J., Roth, R., Goodenough, U., et al. (2014). Ultrastructure and composition of the Nannochloropsis gaditana cell wall. Eukaryot. Cell 13, 1450-1464. doi: 10.1128/EC.00183-14

Scigelova, M., and Crout, D. H. G. (1999). Microbial $\beta$-N-acetylhexosaminidases and their biotechnological applications. Enzyme Microb. Technol. 25, 3-14. doi: 10.1016/S0141-0229(98)00171-9

Scott, G. L., and Warren, J. (2012). Tobacco Production System. U.S. Patent No. WO2013028539A2. Washington, DC: U.S. Patent and Trademark Office.

Sharma, M., Sharma, N. N., and Bhalla, T. C. (2009). Amidases: versatile enzymes in nature. Rev. Environ. Sci. Biotechnol. 8, 343-366. doi: 10.1007/s11157-0099175-x

Singh, A., Agrawal, A. K., Abidi, A. B., and Darmwal, N. S. (1990). Properties of cellobiase from Aspergillus niger. Appl. Microbiol. Biotechnol. 34, 356-358. doi: 10.1007/BF00170059

Singh, G., Verma, A. K., and Kumar, V. (2016). Catalytic properties, functional attributes and industrial applications of $\beta$-glucosidases. 3 Biotech 6:3. doi: 10. 1007/s13205-015-0328-z

Singhania, R. R., Patel, A. K., Sukumaran, R. K., Larroche, C., and Pandey, A. (2013). Role and significance of beta-glucosidases in the hydrolysis of cellulose for bioethanol production. Bioresour. Technol. 127, 500-507. doi: 10.1016/j. biortech.2012.09.012

Sinnot, M. (1998). Comprehensive Biological Catalysis: A Mechanistic Reference. San Diego, CA: Academic Press Inc.

Slade, R., and Bauen, A. (2013). Micro-algae cultivation for biofuels: cost, energy balance, environmental impacts and future prospects. Biomass Bioenergy 53, 29-38. doi: 10.1016/j.biombioe.2012.12.019

Song, J. M., An, Y. J., Kang, M. H., Lee, Y. H., and Cha, S. S. (2012). Cultivation at $6-10{ }^{\circ} \mathrm{C}$ is an effective strategy to overcome the insolubility of recombinant proteins in Escherichia coli. Protein Expr. Purif. 82, 297-301.

Sørensen, A., Lübeck, M., Lübeck, P., and Ahring, B. (2013). Fungal betaglucosidases: a bottleneck in industrial use of lignocellulosic materials. Biomolecules 3, 612-631. doi: 10.3390/biom3030612

Souza, C. A., Li, S., Lin, A. Z., Boutrot, F., Grossmann, G., Zipfel, C., et al. (2017). Cellulose-derived oligomers act as damage-associated molecular patterns and trigger defense-like responses. Plant Physiol. 173, 2383-2398. doi: 10.1104/pp. 16.01680

Stoykov, Y. M., Pavlov, A. I., and Krastanov, A. I. (2015). Chitinase biotechnology: production, purification, and application. Eng. Life Sci. 15, 30-38. doi: 10.1002/ elsc. 201400173
Sutendra, G., Wong, S., Fraser, M. E., and Huber, R. E. (2007). $\beta$-Galactosidase (Escherichia coli) has a second catalytically important $\mathrm{Mg}^{2+}$ site. Biochem. Biophys. Res. Commun. 352, 566-570. doi: 10.1016/j.bbrc.2006.11.061

Synowiecki, J., and Al-Khateeb, N. A. (2003). Production, properties, and some new applications of chitin and its derivatives. Crit. Rev. Food Sci. Nutr. 43, 145-171. doi: $10.1080 / 10408690390826473$

Takeda, H. (1991). Sugar composition of the cell wall and the taxonomy of Chlorella (Chlorophyceae). J. Phycol. 27, 224-232. doi: 10.1111/j.0022-3646.1991.00 224.x

Taunt, H. N., Stoffels, L., and Purton, S. (2018). Green biologics: the algal chloroplast as a platform for making biopharmaceuticals. Bioengineered 9, 48-54. doi: 10.1080/21655979.2017.1377867

Tredici, M. R., Rodolfi, L., Biondi, N., Bassi, N., and Sampietro, G. (2016). Techno-economic analysis of microalgal biomass production in a 1-ha Green Wall Panel (GWP ${ }^{\circledR}$ ) plant. Algal Res. 19, 253-263. doi: 10.1016/j.algal.2016.09. 005

Vaaje-Kolstad, G., Forsberg, Z., Loose, J. S., Bissaro, B., and Eijsink, V. G. (2017). Structural diversity of lytic polysaccharide monooxygenases. Curr. Opin. Struct. Biol. 44, 67-76. doi: 10.1016/j.sbi.2016.12.012

Vaaje-Kolstad, G., Westereng, B., Horn, S. J., Liu, Z., Zhai, H., Sørlie, M., et al. (2010). An oxidative enzyme boosting the enzymatic conversion of recalcitrant polysaccharides. Science 330, 219-222. doi: 10.1126/science. 1192231

Valenzuela, S. V., Valls, C., Schink, V., Sánchez, D., Roncero, M. B., Diaz, P., et al. (2019). Differential activity of lytic polysaccharide monooxygenases on celluloses of different crystallinity. Effectiveness in the sustainable production of cellulose nanofibrils. Carbohydr. Polym. 207, 59-67. doi: 10.1016/j.carbpol. 2018.11.076

Van Zyl, W. H., Rose, S. H., Trollope, K., and Görgens, J. F. (2010). Fungal $\beta$-mannanases: Mannan hydrolysis, heterologous production and biotechnological applications. Process Biochem. 45, 1203-1213.

Verma, D., Kanagaraj, A., Jin, S., Singh, N. D., Kolattukudy, P. E., and Daniell, H. (2010). Chloroplast-derived enzyme cocktails hydrolyse lignocellulosic biomass and release fermentable sugars. Plant Biotechnol. J. 8, 332-350. doi: 10.1111/j. 1467-7652.2009.00486.x

Vermassen, A., Leroy, S., Talon, R., Provot, C., Popowska, M., and Desvaux, M. (2019). Cell wall hydrolases in bacteria: insight on the diversity of cell wall amidases, glycosidases and peptidases toward peptidoglycan. Front. Microbiol. 10:331. doi: $10.3389 /$ fmicb.2019.00331

Villares, A., Moreau, C., Bennati-Granier, C., Garajova, S., Foucat, L., Falourd, X., et al. (2017). Lytic polysaccharide monooxygenases disrupt the cellulose fibers structure. Sci. Rep. 7:40262. doi: 10.1038/srep40262

Vollmer, W., Blanot, D., and De Pedro, M. A. (2008). Peptidoglycan structure and architecture. FEMS Microbiol. Rev. 32, 149-167. doi: 10.1111/j.1574-6976.2007. 00094.x

Wang, H., Li, J., Liu, L., Li, X., Jia, D., Du, G., et al. (2012). Increased production of alkaline polygalacturonate lyase in the recombinant Pichia pastoris by controlling cell concentration during continuous culture. Bioresour. Technol. 124, 338-346. doi: 10.1016/j.biortech.2012.08.027

Wilken, L. R., and Nikolov, Z. L. (2011). Process evaluations and economic analyses of recombinant human lysozyme and hen egg-white lysozyme purifications. Biotechnol. Prog. 27, 733-743. doi: 10.1002/btpr.593

Yamada, R., Taniguchi, N., Tanaka, T., Ogino, C., Fukuda, H., and Kondo, A. (2011). Direct ethanol production from cellulosic materials using a diploid strain of Saccharomyces cerevisiae with optimized cellulase expression. Biotechnol. Biofuels 4:8. doi: 10.1186/1754-6834-4-8

Yeoman, C. J., Han, Y., Dodd, D., Schroeder, C. M., Mackie, R. I., and Cann, I. K. O. (2010). Thermostable enzymes as biocatalysts in the biofuel industry. Adv. Appl. Microbiol. 70, 1-55. doi: 10.1016/S0065-2164(10)70001-0

York, W. S., Qin, Q., and Rose, J. K. C. (2004). Proteinaceous inhibitors of endo- $\beta$-glucanases. Biochim. Biophys. Acta 1696, 223-233.

Zámockỳ, M., Schümann, C., Sygmund, C., O'Callaghan, J., Dobson, A. D. W., Ludwig, R., et al. (2008). Cloning, sequence analysis and heterologous expression in Pichia pastoris of a gene encoding a thermostable cellobiose dehydrogenase from Myriococcum thermophilum. Protein Expr. Purif. 59, 258265. doi: 10.1016/j.pep.2008.02.007

Zhang, J., Xia, W., Liu, P., Cheng, Q., Tahi, T., Gu, W., et al. (2010). Chitosan modification and pharmaceutical/biomedical applications. Mar. Drugs 8, 19621987. doi: $10.3390 / \mathrm{md} 8071962$ 
Zhao, X. Q., Zi, L. H., Bai, F. W., Lin, H. L., Hao, X. M., Yue, G. J., et al. (2012). "Bioethanol from lignocellulosic biomass," in Biotechnology in China III: Biofuels and Bioenergy, eds F. W. Bai, C. G. Liu, H. Huang, and G. T. Tsao (Berlin: Springer), 25-51. doi: 10.1007/10_ 2011_129

Zhong, R., Cui, D., and Ye, Z. (2019). Secondary cell wall biosynthesis. New Phytol. 221, 1703-1723. doi: 10.1111/nph.15537

Zhou, H., Li, X., Guo, M., Xu, Q., Cao, Y., Qiao, D., et al. (2015). Secretory expression and characterization of an acidic endo-polygalacturonase from Aspergillus niger SC323 in Saccharomyces cerevisiae. J. Microbiol. Biotechnol. 25, 999-1006. doi: 10.4014/jmb.1501.01024

Zhuang, J., Marchant, M. A., Nokes, S. E., and Strobel, H. J. (2007). Economic analysis of cellulase production methods for bioethanol. Biosyst. Agric. Eng. Fac. Publ. 23, 679-687.

Zipfel, C. (2014). Plant pattern-recognition receptors. Trends Immunol. 35, 345-351. doi: 10.1016/j.it.2014.05.004
Zverlov, V., Piotukh, K., Dakhova, O., Velikodvorskaya, G., and Borriss, R. (1996). The multidomain xylanase A of the hyperthermophilic bacterium Thermotoga neapolitana is extremely thermoresistant. Appl. Microbiol. Biotechnol. 45, 245-247.

Conflict of Interest: The authors declare that the research was conducted in the absence of any commercial or financial relationships that could be construed as a potential conflict of interest.

Copyright (C) 2020 Giovannoni, Gramegna, Benedetti and Mattei. This is an openaccess article distributed under the terms of the Creative Commons Attribution License (CC BY). The use, distribution or reproduction in other forums is permitted, provided the original author(s) and the copyright owner(s) are credited and that the original publication in this journal is cited, in accordance with accepted academic practice. No use, distribution or reproduction is permitted which does not comply with these terms. 